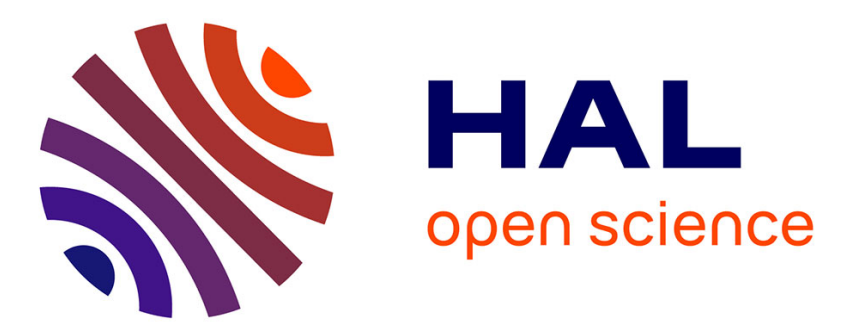

\title{
Predicting generation and expulsion of paraffinic oil from vitrinite-rich coals
}

S. D. Killops, R. H. Funnell, R. P. Suggate, R. Sykes, K. E. Peters, C. Walters, A. D. Woolhouse, R. J. Weston, Jean-Paul Boudou

\section{To cite this version:}

S. D. Killops, R. H. Funnell, R. P. Suggate, R. Sykes, K. E. Peters, et al.. Predicting generation and expulsion of paraffinic oil from vitrinite-rich coals. Organic Geochemistry, 1998, 29, pp.1-29. 10.1016/S0146-6380(98)00087-4 . bioemco-00156951

\section{HAL Id: bioemco-00156951 \\ https://hal-bioemco.ccsd.cnrs.fr/bioemco-00156951}

Submitted on 24 Jun 2007

HAL is a multi-disciplinary open access archive for the deposit and dissemination of scientific research documents, whether they are published or not. The documents may come from teaching and research institutions in France or abroad, or from public or private research centers.
L'archive ouverte pluridisciplinaire HAL, est destinée au dépôt et à la diffusion de documents scientifiques de niveau recherche, publiés ou non, émanant des établissements d'enseignement et de recherche français ou étrangers, des laboratoires publics ou privés. 


\title{
Predicting generation and expulsion of paraffinic oil from vitrinite-rich coals
}

\author{
S. D. KILLOPS'*, R. H. FUNNELL', R. P. SUGGATE', R. SYKES', \\ K. E. PETERS ${ }^{2}$, C. WALTERS 2 , A. D. WOOLHOUSE ${ }^{2}$, R. J. WESTON \\ and J.-P. BOUDOU*
}

'Institute of Geological and Nuclear Sciences, PO Box 30368, Lower Hutt, New Zealand, 'Mobil Exploration and Producing Technical Center, PO Box 650232, Dallas, TX, USA, Industrial Research Ltd., PO Box 31310, Lower Hutt, New Zealand and 'Laboratoire de Geochimie et Metallogenie.

Université Pierre et Marie Curie, 4 Place Jussieu, Paris, France

\begin{abstract}
Rock-Eval HI values for coals vary with rank and do not give a direct measurement of oif potential. However, oils from coals are characteristically paraffinic and can be considered to derive from a polymethylene (PM) component, so the PM content should provide an estimate of the paraffinic oil potential. A trend apparently representing lignin evolution has been identified on the Van Krevelen diagram which permits the relative proportions of carbon in lignin and PM to be determined for coals that approximate a mixture of these two components, such as the members of the New Zealand (NZ) Coal Band. On the basis of this compositional model. HI values can be calibrated to provide an alternative estimate of the paraffinic oil potential. A maximum in $\mathrm{HI}$ is generally reached in coals near the onset of oil generation, at $\operatorname{Rank}(\mathrm{S}) 12\left(R_{\mathrm{o}} c a .0 .7 \%\right)$, from which it is suggested that the PM contribution can be obtained using the formula $\mathrm{HI}_{\mathrm{PM}}=1.15 \mathrm{HI}_{\max }-172$ for the suite of $\mathrm{NZ}$ coals examined. The onset of oil expulsion can be identified from a variety of geochemical measurements, and occurs in the $\operatorname{Rank}(\mathrm{S})$ range $c a .12 .0-14.5\left(R_{0} c a, 0.7-1.1 \%\right)$ for coals with paraffinic oil potentials exceeding ca. $40 \mathrm{mg} \mathrm{HC} / \mathrm{g}$ TOC. Data from Taranaki Basin coals correlate well with the theoretical relationship between $\mathrm{BI} / \mathrm{HI}_{\mathrm{PM}}$ and $\mathrm{HI}_{\mathrm{PM}}$, using bitumen index $(\mathrm{BI}=\mathrm{SI} / \mathrm{TOC}$ ) values of $10 \mathrm{mg} \mathrm{HC} / \mathrm{g}$ TOC at the start of oil generation (i.e. bitumen inherited from diagenesis) and $40 \mathrm{mg} \mathrm{HC} / \mathrm{g} \mathrm{TOC}$ at the onset of oil expulsion, suggesting the HIPM model is reasonably accurate for members of the NZ Coal Band. Kinetic modelling of paraffinic oil generation from vitrinite-rich coals may be best approximated by consideration of PM degradation alone.
\end{abstract}

Key words-coal. New Zealand, rank, polymethylene, lignin, hydrogen index, biomarker maturity parameters, oil generation, oil expulsion. kerogen transformation kinetics

\section{INTRODUCTION}

There is now consensus that coals can have oil potential (Law and Rice, 1993; Scott and Fleet, 1994). For example, Cretaceous and Tertiary coals have been identified as the major sources of oil in the Taranaki Basin, New Zealand (e.g. Killops et al., 1994). Accurate modelling of oil generation and expulsion from coals requires: (1) measurement of the true hydrocarbon potentials of coals, (2) determination of oil-expulsion thresholds and (3) derivation of reliable kinetic data for hydrocarbongenerating reactions. Despite advances in all three areas in recent years for types I and II kerogens, confidence in the resulting models for coals and type III kerogens cannot be considered high. This article examines the criteria for modelling coal, using geochemical data from NZ coals recovered as cuttings from petroleum exploration wells in the Taranaki Basin and from a sequence of coal hor-

-To whom correspondence should be addressed. E-mail: killops (a cawfort.avel.co.uk. izons in Tara-1 well in the Great South Basin which spans a depth range of over $2 \mathrm{~km}$ and the onset of oil generation and expulsion (Killops et al.. 1997).

It might be expected that lignified remains, the major constituents of vitrinite, generate gaseous hydrocarbons and that a significant contribution from liptinites is required for generation of liquid hydrocarbons. However, maceral composition is not necessarily a good guide to the chemical composition of coals (Powell et al., 1991). Not all resistant biomacromolecules that are believed to contribute to kerogen (Tegelaar et al., 1989) have an intrinsically microscopically identifiable structure. For example, cutan is likely to form amorphous bodies upon degradation of the cellulosic epiderm of leaves and increasing pressure. The presence of such amorphous, hydrogen-rich, material probably explains the oil potential of coals that contain little or no liptinite, particularly those rich in desmocollinite (Clayton et al.. 1991). Polymethylenic biomacromolecules like cutan and suberan are expected to yield paraffinic oils charac- 

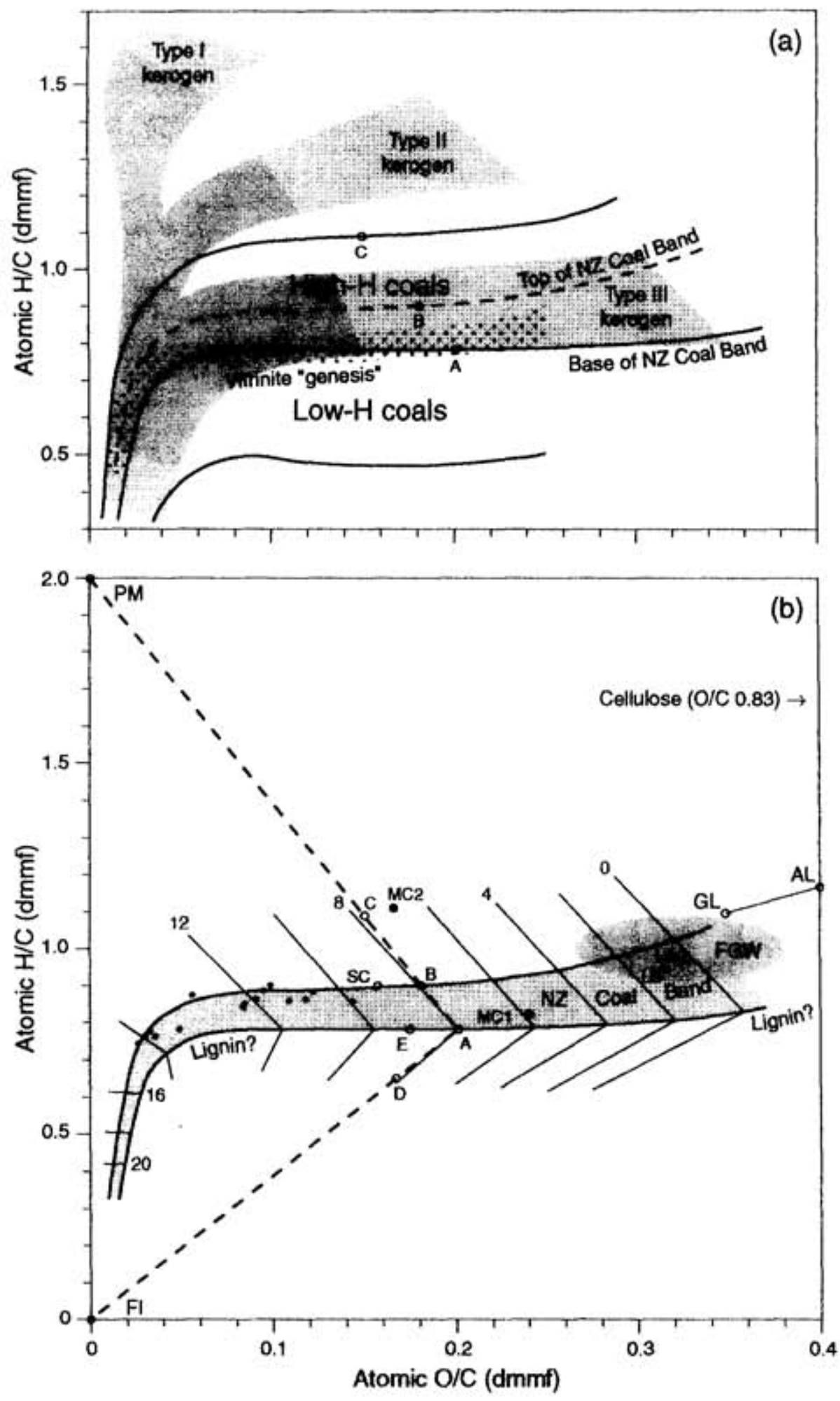

Fig. 1. Van Krevelen diagrams showing the relationship of the New Zealand Coal Band to (a) main kerogen types (half-tone, with zone of catagenesis represented by darker tone: after Behar and Vandenbroucke, 1986) and Van Krevelen's band of vitrinite genesis (stippled band; Van Krevelen, 1961), (b) isoRank(S) contours and end-member chemical components. (See text for discussion of A-E; $\mathrm{PM}=$ polymethylene; $\mathrm{FI}=$ fusinitic inertinite; $\mathrm{MCl}$ and $\mathrm{MC2}$ are Maramarua coals; unlabelled points are Tara coals; GL and AL are modelled gymnospermous and angiospermous lignins, LA and LB are modelled lignites and SC a modelled subbituminous coal (Hatcher, 1990); FGW represents the field of fossil gymnospermous woods (after Hatcher et al.. 1989b); dmmf = dry, mineral-matter-free.) 
teristic of coals (Powell, 1988: Powell et al., 1991; Isaksen et al., 1998).

The Cretaceous and Tertiary coals recovered from petroleum exploration wells in New Zealand are typical members of the New Zealand Coal Band (Fig. 1: Sykes et al., 1992; Suggate and Boudou, 1993), which provides a good example of a coal series in which vitrinite is by far the most abundant maceral ( $>80 \%$, with desmocollinite often being important) and inertinite (particularly fusinite/semifusinite) is rare (Black, 1980, 1984; Curry et al., 1994). The NZ Coal Band lies within the type III kerogen trend of Béhar and Vandenbroucke (1986), and the bottom of both these trends coincide with Van Krevelen's Van Krevelen (1961) band of vitrinite genesis for European and American Carboniferous coals (Fig. I(a)).

Coals can span a wide range of atomic $\mathrm{H} / \mathrm{C}$ ratios on the Van Krevelen diagram, as shown in Fig. 1(a). Coals lying above the base of the NZ Coal Band can be described as high- $\mathrm{H}$ coals because they are relatively hydrogen-rich, and those with the highest atomic $\mathrm{H} / \mathrm{C}$ values are often liptinite-rich (including a few outliers from the NZ Coal Band). Coals below the base of the NZ Coal Band can be termed low-H coals; they are relatively hydrogen-poor and can contain appreciable amounts of inertinite. The NZ Coal Band is not unique, and coals with a similar maceral composition from Japan and the Mahakam Delta (Indonesia) plot as bands overlapping the NZ Coal Band in Fig. I (Suggate and Boudou, 1996), as do many vitrains from Australia. Consequently, it may be possible to extrapolate the inferences for oil generation and expulsion in NZ coals to other, compositionally similar, vitrinite-rich coals.

\section{MATERIALS AND METHODS}

Unfortunately, the experimental procedures employed in obtaining much of the analytical data for coals from petroleum exploration wells in NZ are seldom documented in well completion reports, and the main source of data used in this article (Crisp, 1986) is not an exception. Coals were apparently isolated from cuttings and analysed by a Rock-Eval-type pyrolysis to yield equivalents of the S1, S2 and TOC measurements. Rock-Eval data from 102 Late Cretaceous and Tertiary coals from 6 wells (Kaimiro-1. Mangahewa-1, Stratford-1, Tane-1, Toko-1 and Urenui-1) were used, together with the gas:oil generation indices $\left[\mathrm{GOGI}=\left(\mathrm{C}_{1}-\mathrm{C}_{5}\right) /\left(\mathrm{C}_{5}-\mathrm{C}_{36}\right)\right]$ recorded for 83 of these coals (Crisp, 1986). General maceral and vitrinite reflectance data were reported for 38 of the coals; maceral composition was fairly constant, with a mean vitrinite content of $90 \%$ and $5 \%$ each of liptinite and inertinite (Crisp, 1986). Biomarker data were available for 59 coals from Kaimiro-1.
McKee-1, Mangahewa-1, Maui-4, Tane-1, Toko-1 and Urenui-1 wells in Taranaki from a number of sources (Crisp, 1986; Johnston et al., 1988; Collier and Johnston, 1991), as well as our own unpublished data.

For the new geochemical studies reported on Tara coals, coal-rich intervals were identified from well logs and the coals isolated from washed cuttings by flotation using polytungstate solution (1.7 s.g.). Drilling mud was removed by washing and sieving. All samples were examined microscopically for signs of contamination: non-coaly material was removed and samples suspected of containing caved coals (following reflected light microscopy) were discarded. Maceral content was fairly constant, with means of $90 \%$ vitrinite ( $23 \%$ desmocollinite). $6 \%$ liptinite and $4 \%$ inertinite. Dry coal isolates were milled to a fine powder. Rock-Eval analysis of 18 samples was undertaken by IFP. France, and proximate (8 samples) and uitimate analyses (14 samples) by Coal Research Ltd., NZ. Bitumen was extracted by ultrasonication with dichloromethane after wetting with a small amount of methanol, and fractionation of saturated and aromatic hydrocarbons was achieved by thin layer chromatography on silica gel using hexane eluent. Biomarker distributions were determined by gas chromatography-mass spectrometry using selected ion monitoring (Killops et al.. 1994).

In order to compare variation in the geochemical parameters of coal samples from a number of locations and to correlate these parameters with the onset of oil generation and expulsion, it is necessary to use a thermal maturity scale that is independent of variations in organic matter type. Vitrinite reflectance (VR) measurements can vary significantly with operator (e.g. due to submaceral identification and selection) and can be affected by reflectance suppression, which has been recognised in NZ coals (Newman and Newman, 1982; Sykes et al.. 1992). Transformation ratio and Rock-Eval $T_{\max }$ values are both affected by the type of hydrocarbon precursors present (e.g. Snowdon, 1995). In effect, there is no universal maturity parameter equated to thermal stress. However, the Rank(S) scheme has been developed for NZ coals and is used throughout this article because it is effectively independent of type variations and moisture content (Suggate. 1959; Suggate and Boudou, 1993).

Rank(S) units represent approximately equal increments of temperature $\left(\mathrm{ca}, 10^{\circ} \mathrm{C}\right.$ for a heating rate of $3^{\circ} / \mathrm{Ma}$ ). An empirical relationship between Rank(S) and VR has been established for NZ coals over the VR range $0.5-1.0 \%$ : $\operatorname{Rank}(\mathrm{S})=\left(17.87-3.25 / \mathrm{VR}-0.5 / \mathrm{VR}^{2}\right), \quad$ although it should be noted that for any Rank(S) value VR can vary depending on the composition of the original peat and the depositional environment (Newman and Newman, 1982). or even the moist- 


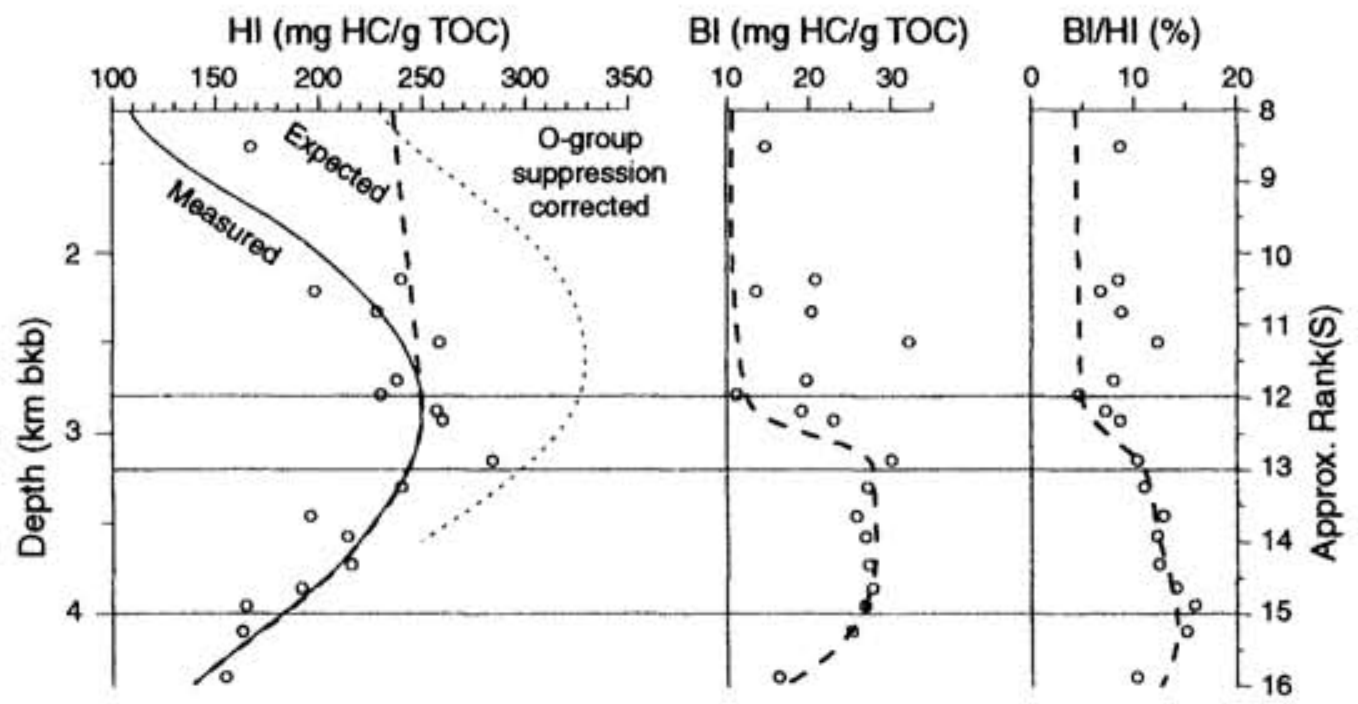

Fig. 2. Variation in Rock-Eval parameters with depth in Tara-1 well. (Average trend of samples represented by solid line; modelled trends shown by bold broken lines; faint broken line gives potential correction of observed $\mathrm{HI}$ trend for O-group suppression.)

ure content for isorank coals (Suggate and Lowery, 1982). The Rank(S) scheme was originally developed using plots of volatile matter vs calorific value (dry, mineral-matter-free basis) or $\mathrm{H}$ vs $\mathrm{C}$ content (dry, mineral-matter-, nitrogen- and sulphur-free basis), and isoRank(S) contours were plotted on the basis of isomaturity samples (Suggate. 1959). The isoRank(S) contours were subsequently transferred to atomic $\mathrm{H} / \mathrm{C}$ vs $\mathrm{O} / \mathrm{C}$ plots on a dry, mineral-matter-free (dmmf) basis (Suggate and Boudou, 1993). Where approx. Rank(S) scales appear on figures, they are derived from estimated apparent linear depth gradients from coal samples in a well. There is a confidence limit of 0.5 of a $\operatorname{Rank}(\mathrm{S})$ unit (imposed by the tolerance criteria for acceptable proximate and ultimate data).

\section{RESULTS AND DISCUSSION}

\section{Petroleum potential and Rock-Eval analysis}

Rock-Eval is a quick and convenient method for examining the petroleum potential of source rocks, and its application and limitations have been documented (c.g. Orr, 1983; Peters, 1986). Coals present particular problems because their abundant pyrolysis products tend to produce a response outside the linear range of the flame ionisation detector (FID), and so small samples are preferable ( $c a$. $10 \mathrm{mg}$ : e.g. Bostick and Daws, 1994). Most coals yield hydrogen indices $(\mathrm{HI})$ of $<300 \mathrm{mg} \mathrm{HC} / \mathrm{g}$ TOC, but it is believed that the hydrocarbon potential of coals is generally overestimated by open pyrolysis systems like Rock-Eval, mainly because thermally-cleaved fragments can readily escape from the kerogen (Monthioux et al., 1986; Peters, 1986: Schenck and Horsfield, 1993). Some coals have little oil potential but $\mathrm{HI}$ values of $200-$ $400 \mathrm{mg} \mathrm{HC} / \mathrm{g}$ TOC because they contain a component (possibly resinitic) that only generates gascondensate range hydrocarbons (Isaksen et al.. 1998).

In this article, $\mathrm{HI}$ is preferred to $\mathrm{S} 2$ when describing petroleum potential because it normalises the potential to $\mathrm{C}$ content, allowing comparison of coals of different maturities and ash content. Similarly, bitumen (i.e. oil-like components) will be considered as SI/TOC (hereafter referred to as bitumen index, BI) rather than $\mathrm{S} 1$. $\mathrm{HI}$ data are presented for coals from Tara-1 well in Fig. 2. An average $\mathrm{HI}$ trend is shown by the solid line, its extension to maturity extremes is based on data for $\mathrm{NZ}$ coals in general. HI reaches a maximum of $c a$. $250 \mathrm{mg} \mathrm{HC} / \mathrm{g}$ TOC at $\operatorname{Rank}(\mathrm{S}) c a, 12-13$. Such maxima are not exhibited by other kerogen types, but appear to be characteristic of all coals and type-III kerogens (in the range $R_{\mathrm{m}} c a, 0.65-0.8 \%$; Durand and Paratte, 1983; Teichmüller and Durand, 1983; Suggate and Boudou, 1993: Bostick and Daws, 1994). They are not expected, if a particular coal has an intrinsic petroleum potential which remains constant until oil generation commences. This variation in $\mathrm{HI}$ has thwarted attempts to derive a simple empirical relationship between $\mathrm{HI}$ and atomic composition (Powell et al., 1991). Mass balance calculations based on atomic composition suggest that $\mathrm{CO}_{2}$ loss from the average member of the NZ Coal Band accounts for an HI increase of no more than $10 \mathrm{mg} \mathrm{HC} / \mathrm{g}$ TOC (Killops et al., 1996), and water evolution (or uptake) has no effect on $\mathrm{HI}$. Yet $\mathrm{HI}$ increases by at least $100 \mathrm{mg} \mathrm{HC} / \mathrm{g}$ TOC up to Rank(S) $c a$. 12. The expected trend in HI, together with the effects of oil 

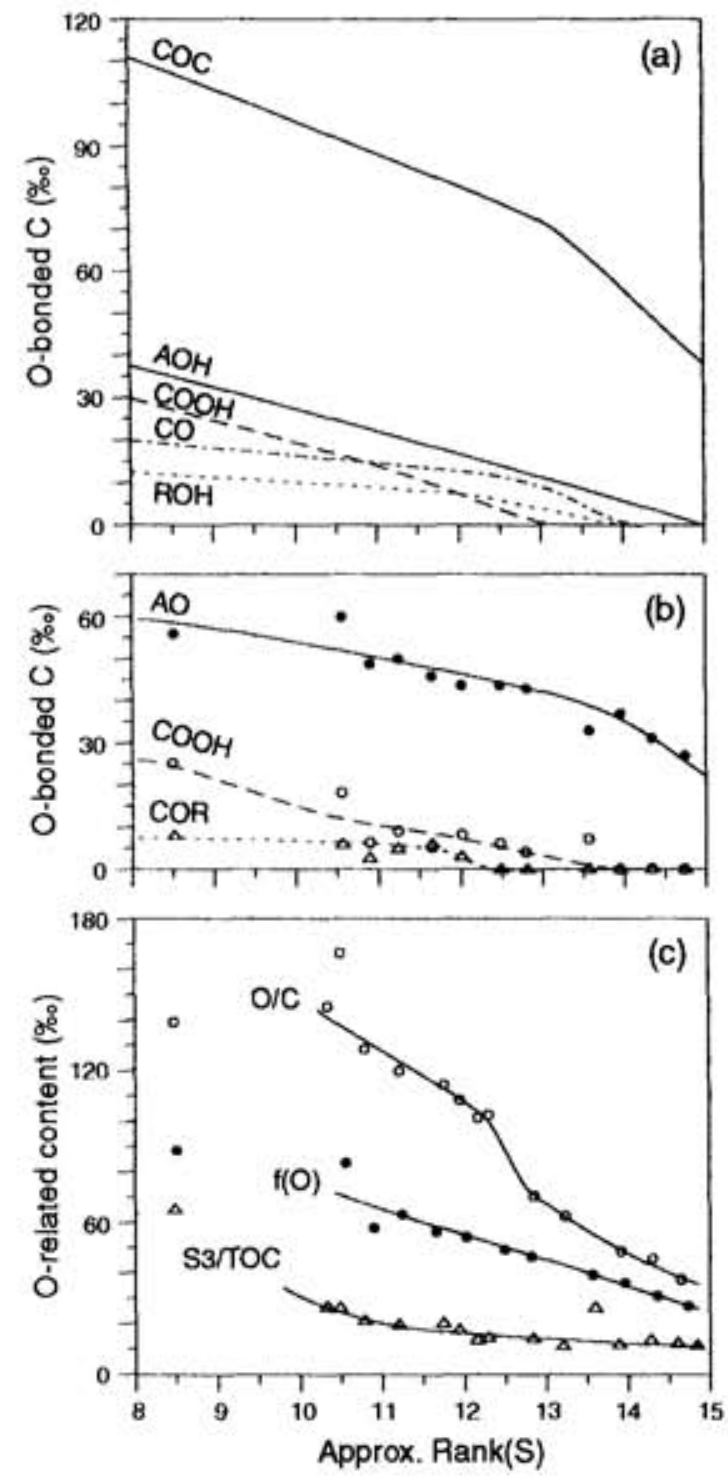

Fig. 3. Rank-related trends in coals from Tara-1 well. (a) Proportion of $\mathrm{O}$-bonded $\mathrm{C}$ from functional group analysis (after Killops ef al., 1996 and references therein: $\mathrm{COC}=$ ether $. \quad \mathrm{AOH}=$ phenolic,$\quad \mathrm{COOH}=$ carboxylic, $\mathrm{CO}=$ carbonyl, $\mathrm{ROH}=$ alkanolic). (b) Proportion of $\mathrm{O}$ bonded $\mathrm{C}$ from ${ }^{13} \mathrm{C}$ NMR analysis (after Dickinson $e t$ al., 1991: $\quad \mathrm{AO}=$ aromatic $\mathrm{O}, \quad \mathrm{COOH}=$ carboxylic . $\mathrm{COR}=$ alkanolic and ether, excluding methoxy). (c) Atomic $\mathrm{O} / \mathrm{C}$ ratio $(\mathrm{O} / \mathrm{C})$, proportion of $\mathrm{O}$-bound $\mathrm{C}[\mathrm{f}(\mathrm{O})]$ from ${ }^{13} \mathrm{C}$ NMR analysis (after Dickinson et al., 1991) and Rock-Eval $\mathrm{CO}_{2}$ yield (S3/TOC).

generation and cracking on $\mathrm{BI}$ and $\mathrm{BI} / \mathrm{HI}$ (assuming an initial $\mathrm{BI}$ of $10 \mathrm{mg} \mathrm{HC} / \mathrm{g} \mathrm{TOC}$ ), are shown by the bold broken lines in Fig. 2. Hydrocarbon generation should result in a significant decrease in $\mathrm{HI}$, and so may commence near the maximum in HI. In Fig. 2 it is assumed to occur at $\operatorname{Rank(S)} 12$ (discussed later). It is necessary to consider whether a meaningful value for hydrocarbon potential can be obtained from $\mathrm{HI}$.
The cause for the apparent suppression of $\mathrm{HI}$ below Rank(S) 12 has not been established unequivocally. One possible explanation is variation in suppression of the FID signal during Rock-Eval analysis (Boudou et al., 1994). The FID responds to $\mathrm{C}$ atoms and the direct $\mathrm{C}$ measurement is usually subjected to a correction factor based on the average $\mathrm{H} / \mathrm{C}$ ratio in the expected products, so that $\mathrm{S} 2$ provides an estimate of hydrocarbon yield (C is assumed to comprise $83 \%$ by weight of products in the Tara data in Fig. 2). However, ionisation is suppressed to varying degrees by $\mathrm{C}$-bonded electronegative atoms. Consequently, the amount by which $\mathrm{C}$ yields are underestimated by a FID depends on the type and number of functional groups present (Sternberg et al., 1962). Immature NZ coals generally have very low $\mathrm{N}$ and $\mathrm{S}$ content, so $\mathrm{O}$ is the main cause of signal suppression. The effects of $\mathrm{O}$ group suppression should be large in lignin and tannin-derived fragments and negligible in the products of cutan and suberan. Based on the maturity-related variation in O-group content of the average member of the NZ Coal Band (Fig. 3(a); Killops et al.. 1996 and references therein) and reported suppression factors (Jorgensen et al., 1990), and allowing for $\mathrm{CO}_{2}$ evolved during the $\mathrm{S} 3$ measurement (Fig. 3(c)), the faint broken line in Fig. 2 shows the possible effects of O-group suppression on the measured HI. The correction for O-group suppression may account for the observed magnitude of $\mathrm{HI}$ variation, but it does not produce the expected trend.

Another scheme has been proposed for correcting measured $\mathrm{HI}$ values in order to compensate for $\mathrm{O}$ group suppression (Boudou et al., 1994). It assumes that petroleum potential equates with $\left(\mathrm{CH}_{2}\right)_{n}$, which may lead to an over-correction of $\mathrm{HI}$ if there is a significant contribution from methane. Corrected $\mathrm{HI}$ for immature coals were significantly higher than measured values and decreased slightly up to the onset of oil generation, which was predicted to occur a little before the maximum in measured $\mathrm{HI}$ (measured $\mathrm{HI}_{\max }$ was $\mathrm{ca}, 85 \%$ of the corrected value at the onset of oil generation; Boudou et al., 1994).

It is not clear whether O-group suppression is the only or even the main factor controlling $\mathrm{HI}$ variation prior to oil generation. Structural rearrangements within coal during diagenesis, as proposed to account for some of the HI variation in Mahakam coals (Boudou et al., 1994), may lead to an increase in potentially hydrocarbon-generating units. A possible mechanism is the recombination of thermallycleaved fragments with kerogen before expulsion occurs, in what would effectively be a closed pyrolysis system. For example, the methyls liberated from methoxy groups on lignin during early diagenesis (discussed later), rather than contributing to early methane generation, may migrate elsewhere 
on the kerogen structure, whereupon they are not subject to O-group suppression. Such rearrangements may reflect progression towards thermodynamic equilibrium in a closed system.

Other factors affect HI values. The pyrolysis conditions used to measure the $\mathrm{S} 1$ peak do not remove all solvent-extractable components from coals (Orr, 1983; Hunt, 1991; Bostick and Daws, 1994). This effect can be seen for three samples from Tara- 1 in Fig. 4. The least mature sample exhibits the largest S2 peak at the lowest $T_{\max }$ value (Fig. 4(a)) and appears to be on the verge of entering the oil window, whereas the other two samples are within the oil window (and post expulsion onset, discussed below). A significant proportion of the $\mathbf{S 2}$ peak of the least mature sample is solvent extractable ( $\mathrm{ca}$. $13 \%$ ), but the effect of this material on $\mathrm{HI}$ diminishes with increasing maturity (Fig. 4(b)). This material appears to be partially represented by the

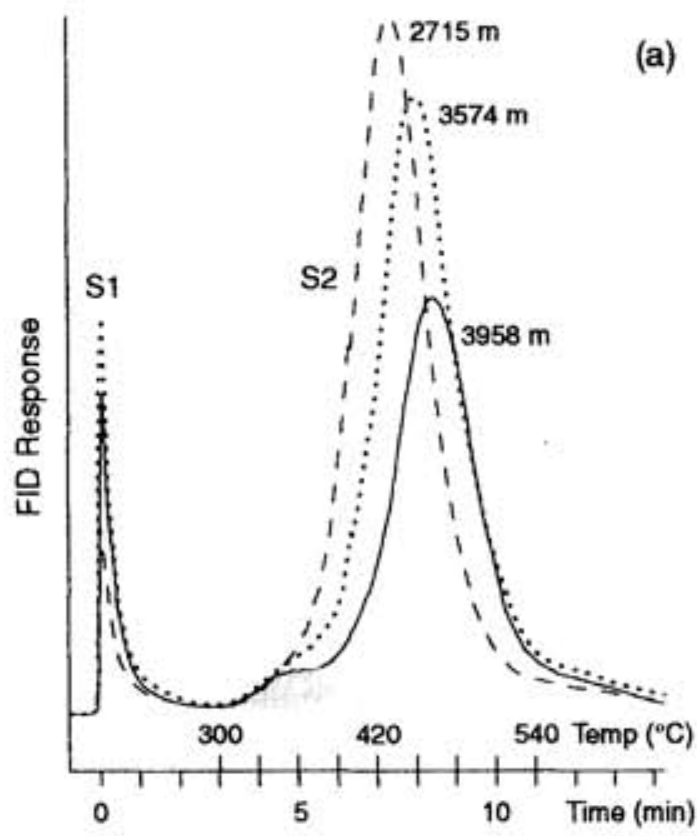

$\mathrm{mg} \mathrm{HC} / \mathrm{g} \mathrm{TOC}$

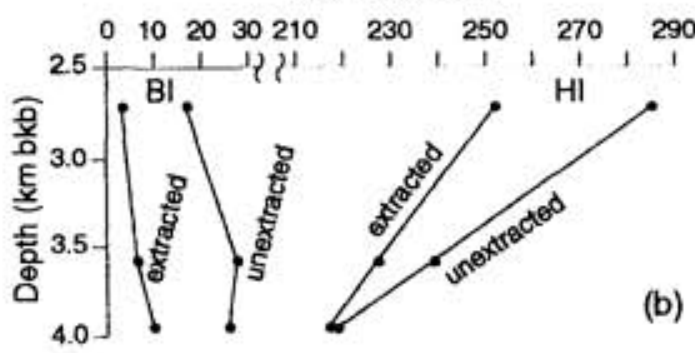

Fig. 4. Rock-Eval data for three coal samples from Tara1 well. (a) Pyrograms for unextracted samples (half-tone area represents potential kerogen-degradation products not liberated during S1 measurement). (b) Variations in BI and $\mathrm{HI}$ between solvent extracted and non-extracted aliquots. shoulder on the low-temperature side of the S2 peak (half-toning, Fig. 4(a)), which is reduced in size following non-exhaustive solvent extraction. The shoulder may be present at all maturities, but can only be distinguished as the main S2 peak moves to higher $T_{\max }$ with increasing maturity. If it represents a symmetrical peak (Fig. 4(a)), it accounts for $c a .7 \%$ of S2 (ca. $10 \%$ of TOC).

If the extractable material is considered an adsorbed oil component. that would normally be expelled under natural conditions, $\mathrm{HI}$ may overestimate the residual petroleum potential by $\mathrm{ca}$. $10 \%$ (on top of any other effects) as the oil window is approached. Alternatively, the material may represent real petroleum precursors. In immature coals it could comprise components similar to classical asphaltenes, whereas in the oil window a greater proportion may correspond to fragments of cutan/ suberan as well as lignin. Asphaltene-like material has a significantly lower $\mathrm{H} / \mathrm{C}$ ratio than cutan/suberan products, so the applied conversion factor may cause the hydrocarbon quantities represented by $\mathrm{S} 2$ to be overestimated. In addition, the change from oil to mainly methane at higher maturities suggests that $\mathbf{S} 2$ is better expressed as unconverted $\mathbf{C}$ values, as recommended by Orr (1983).

Rock-Eval TOC appears little affected by solvent extraction, even though some $36 \%$ of the TOC value is derived from the S2 peak in the least mature sample in Fig. 4 and subject to O-group suppression. Rock-Eval TOC and ultimate $\mathrm{C}$ values are virtually identical (Fig. 5(a); S3 C is included in the TOC value), although TOC values are expected to be slightly lower due to the effect of O-group suppression of the $\mathrm{S} 1$ and $\mathrm{S} 2$ signals and omission of $\mathrm{CO}_{2}$ loss ( $\mathrm{S} 3$ is routinely excluded from the TOC calculation). The possibly slight overestimation of Rock-Eval TOC may be reflected by the residual (non-hydrocarbon-generating) C measurement S4 being some $2-4 \%$ higher than proximate analysis fixed-C (Fig. 5(b)), although the difference may be caused by removal of less of the volatiles during the S1-S3 pyrolysis than during proximate analysis. It is apparent that Rock-Eval TOC measurements for coals can be reasonably accurate when suitably calibrated.

An estimate of hydrocarbon yields independent of O-group suppression can be obtained from ultimate and proximate data. $\mathrm{S} 1+\mathrm{S} 2 \mathrm{C}$ is approximated by (ultimate $\mathrm{C})-($ proximate fixed $\mathrm{C})-(\mathrm{S} 3$ C). from which an $\mathrm{S} 2$ value can be derived by assuming the $\mathrm{C}$ value can be apportioned between $\mathrm{S} 1$ and $\mathrm{S} 2$ according to the measured $\mathrm{S} 1: \mathrm{S} 2$ ratios. The $\mathrm{S} 2 \mathrm{C}$ can be converted to a hydrocarbon yield assuming $83 \% \mathrm{C}$ content, which can then be normalised to ultimate $\mathrm{C}$ to provide $\mathrm{HI}$ values. The resulting depth trend in Fig. 5(c) is of the expected shape (Fig. 2), but $\mathrm{HI}$ exceeds $300 \mathrm{mg} \mathrm{HC} / \mathrm{g} \mathrm{C}_{\text {org }}$ at $\operatorname{Rank}(\mathrm{S}) 12\left(\mathrm{C}_{\text {org }}\right.$ is used instead of TOC to denote 

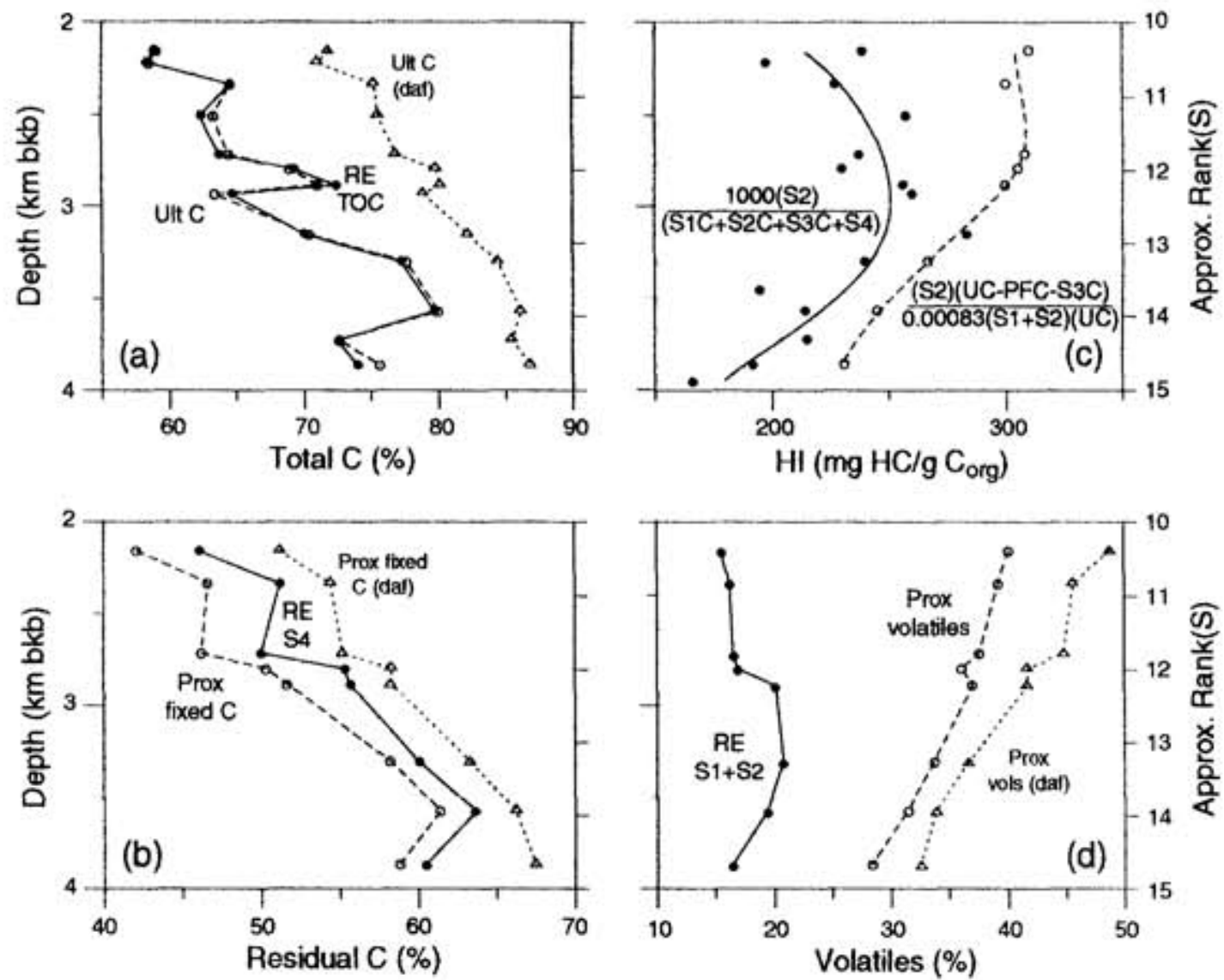

Fig. 5. Comparison of data from Rock-Eval with those from proximate and ultimate analyses of Tara coals. (a) Rock-Eval TOC and ultimate C content. (b) Rock-Eval residual C (S4) and proximate fixed C. (c) Measured and corrected $\mathrm{HI}$ [UC $=$ ultimate $\mathrm{C}, \mathrm{PFC}=$ proximate fixed $\mathrm{C}, \mathrm{SIC}$ and $\mathrm{S} 2 \mathrm{C}=$ Rock-Eval S1 and S2 $\times 0.83, \mathrm{~S} 3 \mathrm{C}=($ Rock-Eval S3) $\times(12 / 440), \mathrm{S} 4=$ Rock-Eval residual $\mathrm{C})$. (d) Rock-Eval S1 + S2 and proximate volatile matter. (Some proximate and ultimate data on a dry. ash-free (daf) basis are shown for comparison.)

that the $\mathrm{C}$ measurement is not from Rock-Eval analysis). Again. a slight overestimation of $\mathrm{HI}$ is expected because $\mathrm{S} 3$ underestimates $\mathrm{CO}_{2}$ loss.

To summarise, there are several factors that can affect Rock-Eval HI values, so it is not clear how accurately the measured or any of the adjusted $\mathrm{HI}$ values near the onset of oil generation represent the true hydrocarbon potential, without a thorough investigation of potential errors in Rock-Eval, ultimate and proximate analyses of coals. Not all the C-containing compounds released during the S2 measurement will contribute to natural hydrocarbon accumulations. Mass balance calculations based on observed atomic $\mathrm{CHO}$ variations for the average member of the NZ Coal Band suggest the total amount of hydrocarbons generated during catagenesis is $220-290 \mathrm{mg} \mathrm{HC} / \mathrm{g} \mathrm{C}_{\text {org }}$ (Killops et al., 1996). which is similar to the range spanned by measured and corrected $\mathrm{HI}_{\max }$ values in Fig. 5(c).

\section{Hydrocarbon potential and elemental analysis}

Oils from coals are typically highly paraffinic, and NZ examples are no exception (e.g. Czochanska et al., 1987; Killops et al., 1994). It has been suggested that estimates of the petroleum potential of coals would be more accurate if based on the paraffinic component (Powell et al.. 1991: Smith et al.. 1994). It is possible to estimate paraffinic oil potential from Van Krevelen diagrams, provided: (1) the oil-generating component can be approximated by $\left(\mathrm{CH}_{2}\right)_{n}$ (polymethylene). (2) the polymethylene contribution can be estimated and (3) direct generation of methane from polymethylene is negligible. To determine the polymethylene contribution requires a baseline of zero polymethylene to be identified, corresponding to predominantly lignin and its diagenetic products. There is evidence for such an evolutionary trend for lignin.

An interesting property of the isoRank(S) contours is the sharp angle at the base of the NZ Coal 
Band (Fig. 1(b)), when a more gentle curve might be anticipated (Newman and Newman, 1982). It can be explained if the base of the NZ Coal Band represents the trend for pure lignin, and coals lying above it comprise mainly mixtures of lignin and polymethylenic material (PM; Fig. I(b)), whereas those below contain mixtures of lignin with fusinitelike inertinite (Fl; Fig. 1(b)). PM in immature samples has an atomic $\mathrm{H} / \mathrm{C}$ ratio of 2 , and $\mathrm{FI}$ is a large polyaromatic structure with an effective $\mathrm{H} / \mathrm{C}$ ratio of 0 , so isoRank(S) lines for immature samples extrapolate to $\mathrm{H} / \mathrm{C}=2$ (cf. Saxby, 1977) and $\mathrm{H}$ / $\mathrm{C}=0$ from the lignin trend. With increasing maturity, as the main down-turn in the NZ Coal Band is approached, isoRank(S) lines above the proposed lignin trend extrapolate to successively lower atomic $\mathrm{H} / \mathrm{C}$ values, which can be interpreted as the result of PM cracking and the consequential disproportionation of $\mathrm{H}$ into $n$-alkanes. $\mathrm{H}$ loss from PM may be offset to some extent by an external source, such as water (cf. Saxby, 1980; Stalker et al., 1994).

On this basis, $\mathrm{C}_{\mathrm{PM}}: \mathrm{C}_{\text {lignin }}$ in an immature coal [up to $\operatorname{Rank}(\mathbf{S}) \mathrm{ca}$. 12] comprising a PM-lignin mixture is given by its position on the line joining pure $\mathrm{PM}(\mathrm{H} / \mathrm{C}=2)$ to the lignin evolution line at the required Rank(S) value. For example, at Rank(S) 8 , $\mathrm{C}_{\mathrm{PM}} /\left(\mathrm{C}_{\mathrm{PM}}+\mathrm{C}_{\text {lignin }}\right)$ for coal $\mathrm{B}$ equals the length ratio A-B/A-PM (Fig. I(b)) or ca. 10\%. Up to a Rank(S) value of ca. 12, the upper boundary of the NZ Coal Band represents a reasonably constant $10 \% \mathrm{C}_{\mathrm{PM}}$, and the upper limit of high- $\mathrm{H}$ coals $(\mathrm{C}$, Fig. 1) corresponds to $c a .26 \% \mathrm{C}_{\mathrm{PM}}$. The hydrocarbon potential of the PM component of a ligninPM mixture is obtained by multiplying the theoretical $\mathrm{HI}$ value for pure PM (1167 $\mathrm{mg} \mathrm{HC} / \mathrm{g} \mathrm{C}_{\text {org }}$ ) by the proportion of $\mathrm{C}_{\mathrm{PM}}$ present (117 and $303 \mathrm{mg}$ $\mathrm{HC} / \mathrm{g} \mathrm{C}_{\text {org }}$ for $\mathrm{B}$ and $\mathrm{C}$, respectively).

That the Rank(S) scheme works for NZ coals (e.g. Suggate, 1959; Suggate and Boudou, 1993) suggests that this simplified compositional picture is a reasonable approximation. Mixtures of all three components - lignin. PM and FI - would tend to blur the Rank(S) distinctions. For example, a mixture of Rank(S) 8 samples of B and D would not plot at point $\mathrm{A}$ but at $\mathrm{F}$, at $\operatorname{Rank}(\mathrm{S}) c a$. 9. Whether or not the lignin evolution line has been correctly identified, such ternary mixtures would cause a problem for the Rank(S) scheme, but they appear to be uncommon among NZ coals. The Rank(S) confidence limit of 0.5 theoretically corresponds to addition of up to $4 \% \mathrm{FI}$ in a lignin-PM mixture. It should be emphasised that three chemical end-members are being considered, which do not necessarily correspond to distinct submaceral groups (e.g. some inertinite submacerals may be chemically more like lignin than FI). The apparent preferential mixing of lignin with either PM or inertinite may not be confined to NZ coals, because a sharp angle in isore- flectance contours over the $R_{\mathrm{o}}$ range $0.6-1.0 \%$ has been noted in U.S. coals (Fig. 7(a) of Bostick and Daws, 1994) at an atomic $\mathrm{H} / \mathrm{C}$ ratio of $\mathrm{ca} .0 .8$.

There is further support for the existence of a discrete lignin trend. It is recognised that cellulosic material degrades rapidly and makes only minor contributions to woody material after the initial phase of peatification (Stout et al., 1988; Hatcher et al., 1989a). Lignin is the major surviving component; that from gymnosperms is predominantly derived from coniferyl alcohol, bearing one methoxy group per aromatic ring. whereas angiospermous lignin also contains a proportion of sinapyl units, bearing two methoxy groups (e.g. SaizJimenez and de Leeuw, 1986). In Fig. 1(b). GL represents a partial structure for gymnospermous lignin (Hatcher, 1990), in comparison with which angiospermous lignins would tend to plot towards $\mathrm{AL}$. This compositional trend is almost perpendicular to isoRank(S) lines and might be predicted to interfere severely with the Rank(S) scheme, because Eocene NZ coals are predominantly derived from angiosperms whereas their Late Cretaceous counterparts are mainly of gymnosperm origin (e.g. Killops et al., 1995). However, demethylation of methoxy groups occurs rapidly during early diagenesis (Hedges et al., 1985; Stout et al., 1988; Hatcher et al., 1989a,b; Hatcher, 1990), so lignin compositions probably rapidly converge, permitting the application of the Rank(S) scheme to angiosperm- and gymnosperm-derived coals on Van Krevelen diagrams.

The area labelled FGW in Fig. 1(b) represents fossil gymnospermous woods derived from podocarps and araucarians (Yallourn brown coals, Victoria; Hatcher et al., 1989b), which were also the main gymnosperms in Late Cretaceous and Paleocene coal swamps in NZ (e.g. Killops et al., 1995). Also shown are modelled structures for two lignites (LA and LB) and a subbituminous coal (Hatcher, 1990). All these data could suggest that lignin evolves along a trend within but above the base of the NZ Coal Band. However, vitrinites in the upper part of this band contain much hydrogen-rich material, and it has also been noted that it is difficult to discount the presence of such material in the structurally-modelled lignite and subbituminous coal samples (Hatcher, 1990). The available data are, therefore, consistent with lignin evolution coinciding with the lower limit of the NZ Coal Band (Fig. 1).

The calculation of PM content (and hence paraffinic oil potential) does not take into account possible contributions of resins to coals (and the resulting oils). Resin contributions appear to be minor, but would cause paraffinic oil potential to be underestimated slightly because $\mathrm{H} / \mathrm{C}$ ratios are $<2$ for the major cycloalkanes and arenes likely from the resins of NZ coals (e.g. isopimarane, olea- 


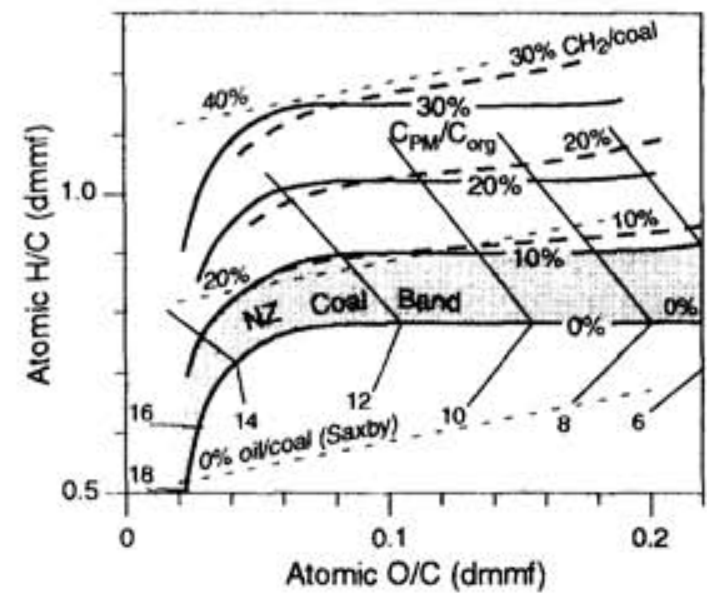

Fig. 6. Potential oil yields of coals based on atomic $\mathrm{CHO}$ composition. (Atomic composition calculated on dry, mineral-matter-free basis $(\mathrm{dmmf})$. Solid lines $=$ oil $/ \mathrm{C}_{\mathrm{org}}$ for PM-derived oil (i.e. $\mathrm{C}_{\mathrm{PM}} / \mathrm{C}_{\mathrm{erz}}$ ), $0 \%=$ lignin evolution line. Bold broken lines $=$ oil $/$ coal wt. $\%$ for PM-derived oil. Faint broken line $=$ Saxby's total oil/coal weight yield (Saxby. 1980; Saxby and Shibaoka, 1986).)

nane, retene and dimethylpicene). It has recently been proposed that there is an aryl backbone to cutan comprising ca. $9 \%$ of $\mathrm{C}_{\text {cutan }}$ (McKinney et al., 1996), so the initial $\mathrm{H}^{\prime} \mathrm{C}$ ratio for cutan could be as low as 1.85, if the proposed ester-linkages between the PM side-chains and the aryl back-bone are preserved during diagenesis. Again, a slight underestimation of PM content would result. All these potential minor underestimations are offset to a degree by some gaseous hydrocarbon production during the primary cracking of PM.

Contours of the percentage of $\mathrm{C}_{\mathrm{PM}}$ in a $\mathrm{PM}$ lignin mixture obtained from the proposed model are shown by solid lines in Fig. 6 (e.g. Tara coals fall on the $c a .8 .5 \% \mathrm{C}_{\mathrm{PM}}$ contour); they are almost thermal evolution lines. Another set of contours, representing the trends in the fractional weight of coal (dmmf) that can be converted to paraffinic oil, are shown by the bold broken lines in Fig. 6 , together with the corresponding contours (faint broken lines) derived from Saxby's empirical model (Saxby. 1980; Saxby and Shibaoka, 1986). Although the contours of fractional coal conversion to oil for the two models have similar gradients over most of the maturity range in Fig. 6, those of Saxby give slightly higher potentials, mainly because they represent total oil potential.

Total petroleum potential is very difficult to predict because of the varying $\mathrm{H} / \mathrm{C}$ ratios of potential precursors and products. Mass balance calculations suggest the average member of the NZ Coal Band at the onset of catagenesis has a potential yield of $80-110 \mathrm{mg} \mathrm{CH}_{4} / \mathrm{g} \mathrm{C}_{\text {org }}$ (Killops et al., 1996). A ${ }^{13} \mathrm{C}$ NMR-based structural model for subbituminous coal suggests 3-4 alkyl C atoms per aromatic ring, on average (Hatcher, 1990), so if virtually all propyl groups have been retained during diagenesis and are subsequently eliminated as methane during catagenesis, there could be as much as $350 \mathrm{mg} \mathrm{CH}_{4} / \mathrm{g}$ $\mathrm{C}_{\text {org }}$ generated. However, pyrolysis studies of Mahakam and North Sea coals suggests that only ca. $30 \mathrm{mg} \mathrm{CH}_{4} / \mathrm{g} \mathrm{C}_{\text {org }}$ is generated under open pyrolysis conditions (Béhar et al., 1997b).

\section{Oil generation threshold}

In Fig. 7 various geochemical parameters are plotted against depth/Rank(S) for coals from Tara1 well. BI exhibits a scatter above $c a .3 .2 \mathrm{~km}$ depth. but is reasonably constant at greater depth. The higher, constant value can be interpreted as representing the saturation capacity of coal for bitumen and that expulsion begins near $3.2 \mathrm{~km}$ depth. or Rank(S) 13. BI values vary widely at shallower depth because of coal-type variation and trapping of migrated hydrocarbons beneath immature coal horizons. A possible explanation for $\mathrm{Bl}$ values $>100 \mathrm{mg} \mathrm{HC} / \mathrm{g}$ TOC for some immature coals in exploration wells is the release of overpressure causing exudation of migrated oil into the recovered cuttings. The variability in $\mathrm{BI}$ above $\mathrm{ca} .3 .2 \mathrm{~km}$ in Tara-1 makes the onset of oil generation difficult to establish with certainty using this parameter alone.

The appearance of petroleum-like material in NZ coals occurs at Rank(S) 9-10 (Suggate and Boudou, 1993), but the geochemical parameters in the lower part of Fig. 7 provide little evidence for significant generation of the components characteristic of NZ coal-sourced oils until $\operatorname{Rank}(\mathrm{S}) c a .12$. For example, $\mathrm{CPI}$ in the $\mathrm{C}_{25}-\mathrm{C}_{31}$ range is high $(>1)$ in immature coals, reflecting the contribution of wax-derived $n$-alkanes to the bitumen present at the end of diagenesis (hereafter termed initial bitumen). Cracking of PM results in $n$-alkanes with $\mathrm{CPI}=1$, so the CPI of bitumen is expected to decrease as the contribution of $n$-alkanes from PM cracking rises, reaching a minimum when expulsion and effective flushing of initial bitumen have occurred. Such a maturity-related trend has been reported for a suite of German Carboniferous bituminous coals (Radke et al., 1980), and for Mahakam coals (Bjorøy et al. 1988), CPI values appear to begin declining above $\operatorname{Rank}(\mathrm{S}) 12$ for Tara coals (Fig. 7). Similarly, the bitumen in immature Tara coals generally contains high proportions of $17 \alpha(\mathrm{H})$-homohopanes, presumably derived from decarboxylation of 31,32-bishomohopanoic acid, a compound generally abundant in peats and soils (Quirk et al., 1984; Ries-Kautt and Albert, 1989). whereas the hopanes of coal-derived oils are dominated by $17 \alpha(\mathrm{H})$-hopane (Killops et al., 1994). The proportion of $17 \alpha(\mathrm{H})$-hopane does not increase noticeably until nearly Rank(S) 12.5 .

Without absolute quantification of biomarkers in initial bitumen and thermally-generated hydrocarbons, it is not possible to discount that changes in 

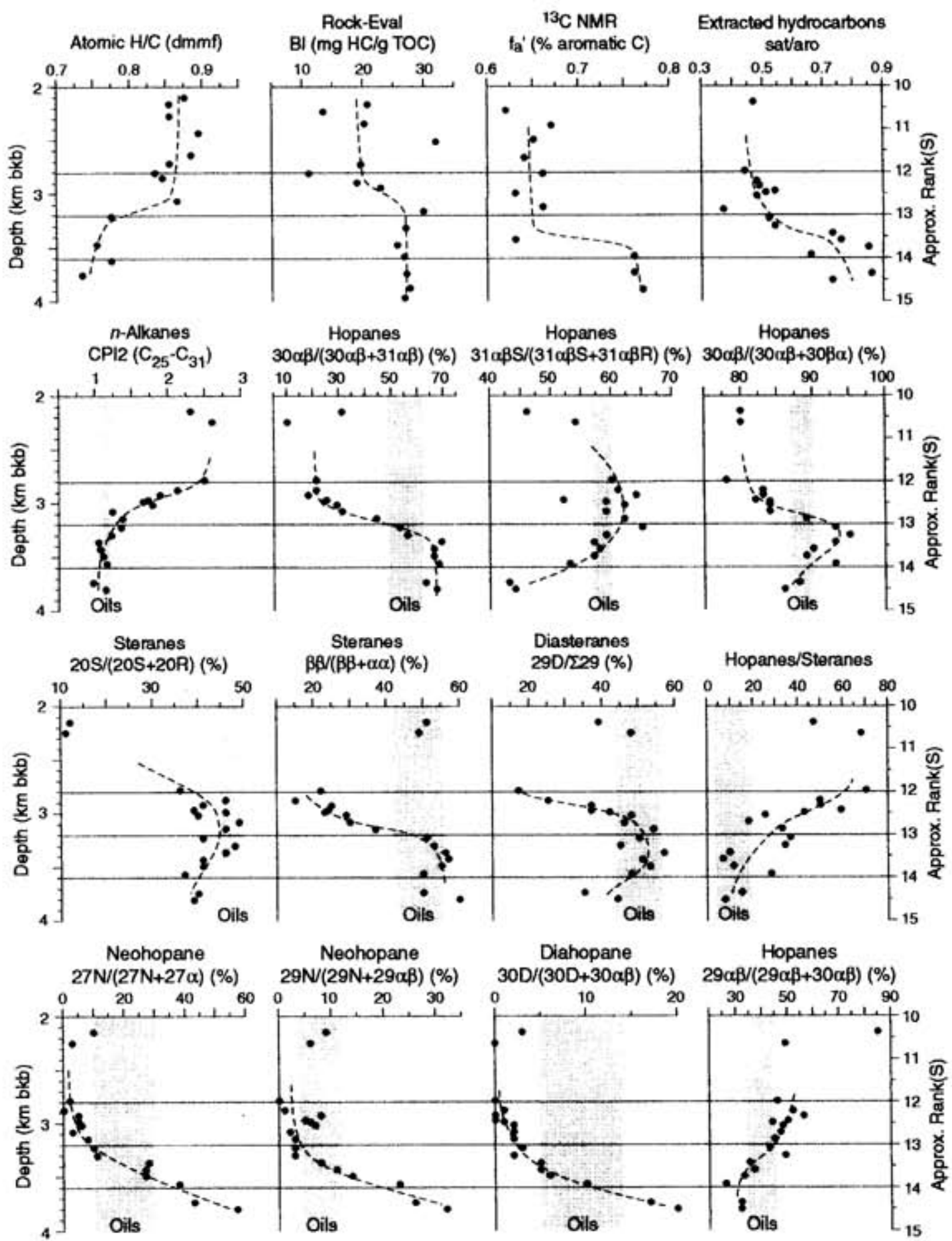

Fig. 7. Depth trends in various geochemical parameters for coals in Tara- 1 well. $\left({ }^{13} \mathrm{C}\right.$ NMR data and $f_{a}^{\prime}$ after Dickinson et al., 1991. CPI2 (Marzi et al., 1993) based on m/z 183 responses for $C_{25}-C_{31} n$ alkanes. Hopane ratios based on $\mathrm{m} / z 191$ response; $27 \alpha, 29 x \beta$ and $30 x \beta=\mathrm{C}_{27}, \mathrm{C}_{29}$ and $\mathrm{C}_{30} 17 x(\mathrm{H})$ hopanes: $30 \beta \alpha=17 \beta(\mathrm{H})$-moretane: $31 \alpha \beta \mathrm{S} / \mathrm{R}=22 \mathrm{~S} / \mathrm{R}-17 \alpha(\mathrm{H})$-homohopane; $27 \mathrm{~N}$ and $29 \mathrm{~N}=\mathrm{C}_{27}$ and $\mathrm{C}_{29} \quad 18 x(\mathrm{H})$-neohopanes; $30 \mathrm{D}=17 \alpha(\mathrm{H})-15 \alpha \cdot$ methyl-27-norhopane (i.e. diahopane). Sterane ratios based on $m / z 217$ response: $20 \mathrm{~S} / \mathrm{R}=20 \mathrm{~S} / \mathrm{R}$ epimers of $5 x(\mathrm{H}), 14 x(\mathrm{H}), 17 x(\mathrm{H})$-24-ethylcholestane, $\beta \beta=5 x(\mathrm{H}), 14 \beta(\mathrm{H}), 17 \beta(\mathrm{H})$-24-ethylcholestanes, $\alpha x=5 x(\mathrm{H}), 14 \alpha(\mathrm{H}), 17 \alpha(\mathrm{H})$-24-ethylcholestanes, $29 \mathrm{D}=$ $13 \beta(\mathrm{H}), 17 \alpha(\mathrm{H})-24$-ethyldiacholestanes, $\Sigma 29=$ sum of $5 x(\mathrm{H})-24$-ethylcholestanes and $13 \beta(\mathrm{H}), 17 \alpha(\mathrm{H})-24$ ethyldiacholestanes. Hopanes/steranes based on ratio of $\mathrm{m} / \mathrm{z}$ 19I response for $\mathrm{C}_{29}-\mathrm{C}_{31} 17 x(\mathrm{H})$-hopanes and $17 \beta(\mathrm{H})$-moretanes to $\mathrm{m} / \mathrm{z} 217$ response for $\mathrm{C}_{27}-\mathrm{C}_{29} 5 x(\mathrm{H})$-steranes and $13 \beta(\mathrm{H}), 17 \alpha(\mathrm{H})$-diasteranes. Half-tone bands represent parameter ranges for NZ coal-sourced oils.) 
biomarker parameters only become apparent at the onset of oil expulsion rather than at the onset of generation. However, the fact that generated oils are more paraffinic $\left(f_{a}^{\prime}\right.$, sat/aro; Fig. 7$)$ and have a higher hopane/sterane ratio (Fig. 7) than the initial bitumen suggests that the onset of distinct changes in $30 \alpha \beta /(30 \alpha \beta+31 \alpha \beta)$ and CPI in Fig. 7 probably represents the start of significant paraffinic oil generation. at $\operatorname{Rank}(\mathrm{S}) c a .12$ (VR $c a .0 .65 \%$ ). This infers that the kinetics of biomarker and $n$-alkane generation from kerogen are virtually identical. However, in the case of factors affecting CPI, there is potentially an earlier source of $n$-alkanes than PM cracking, the thermal degradation of wax esters (Alexander et al., 1992). The $n$-alkanol part yields alkanes with even $\mathrm{C}$-number preservation (Alexander et al., 1992), whereas the $n$-alkanoic acid part may undergo decarboxylation to yield odd-numbered alkanes. The overall effect of waxester degradation on CPI also depends on the Cnumber distributions in the acid and alcohol precursors. It can also be speculated from the recently proposed structure for cutan (McKinney et al., 1996) that the ester-bonded polymethylenic sidechains would be released by decarboxylation before cracking of the long chains occurs. This release of PM chains might help to explain the appearance of petroleum-like substances at Rank(S) 9-10 (VR ca. $0.5 \%$ ). The functional group and NMR data for NZ coals (Fig. 4(a) and (b)) suggest that ester-C contributions are at most $25 \% \mathrm{C}_{\text {org }}$ at $\operatorname{Rank}(\mathrm{S}) 9$ and $8 \%$ at $\operatorname{Rank}(\mathrm{S})$ 12. The apparent early generation of $\mathrm{C}_{24} \mathrm{cf}$. $\mathrm{C}_{12}$ n-alkane in kerogen isolates from some other coals (Béhar et al., 1997a) may be due to a wax-ester source for $n-\mathrm{C}_{24}$ or the presence of adsorbed bitumen containing wax $n$-alkanes.

\section{Oil expulsion threshold}

Expulsion of paraffinic oil should cause a decrease in the atomic $\mathrm{H} / \mathrm{C}$ ratio and an increase in the aromatic fraction of the ${ }^{13} \mathrm{C}$ NMR signal $\left(f_{a}^{\prime \prime}\right.$; Newman et al., 1988) of bulk coal samples (i.e. including bitumen), together with an increase in the sat/aro ratio of extracted hydrocarbons. These trends occur at Rank(S) 13-14 in Fig. 7. Some predictions can be made about bitumen composition, if it is assumed that the extractability of the thermally generated paraffinic components are no different from those in the initial bitumen. At the onset of expulsion the contribution of initial bitumen should decrease, although some geochemical parameters may not show this effect as markedly as others because of variations in the abundance of individual components in the initial bitumen compared to the thermally-generated bitumen. It might also be expected that the effects of the initial bitumen would linger after the onset of expulsion until flushing is complete, so not all geochemical parameters will necessarily reach their values in thermally-gen- erated oil at the onset of expulsion. From Fig. 7. expulsion appears to begin in Tara coals at Rank(S) 13 and flushing is effectively complete by $\operatorname{Rank(S)~14,~consistent~with~data~from~coal-sourced~}$ NZ oils (half-tone bands, Fig. 7).

Expulsion-related effects may account for the observed discontinuities in compositional trends of bitumen extracted from some German bituminous coals at $R_{\mathrm{m}} c a .0 .9 \%$ (Radke et al., 1980), which corresponds to $\operatorname{Rank}(\mathrm{S}) c a$. 13.5. Similarly, BI has been found to reach a maximum at $c a .0 .9 \% R_{m}$ in a range of other coals (Teichmüller and Durand. 1983), consistent with the onset of expulsion.

\section{Biomarker maturity parameters}

Various biomarker parameters are represented in Fig. 7 which have been considered indicators of maturity (e.g. Peters and Moldowan, 1993). For some time it has been thought that thermallyinduced isomerisations account for the observed variations in stereochemistry at C-22 and C-17/C-20 in hopanes, and at $\mathrm{C}-20$ and $\mathrm{C}-14 / \mathrm{C}-17$ in steranes, resulting in an increase in the relative amounts of the more thermodynamically-stable configurations with rising thermal stress until equilibria are established. So the apparent decrease in the ratios $31 \alpha \beta S /(31 \alpha \beta S+31 \alpha \beta R)$ and $30 \alpha \beta /(30 \alpha \beta+30 \beta \alpha)$ for hopanes and $20 S^{\prime}(20 S+20 R)$ for steranes at $\operatorname{Rank}(\mathrm{S})>13$ in Fig. 7 is unexpected. However, it can be explained by a combination of differences in isomer distributions between initial bitumen and thermally generated hydrocarbons, and variation in the relative rates of generation from kerogen and subsequent thermal destruction of individual components (Peters et al., 1990; Bishop and Abbott, 1993; Requejo, 1994: Dzou et al., 1995; Farrimond et al., 1996). Thermal destruction of biomarkers is a major factor close to dykes (Bishop and Abbott. 1993; Farrimond et al., 1996), and may affect saturates in general more than aromatic hydrocarbons (Clayton and Bostick, 1986). Under more normal heating rates, apparent concentrations of hopanes and steranes in the Upper Devonian Duvernay Formation of Western Canada decrease as $T_{\max }$ exceeds ca. $440^{\circ} \mathrm{C}$ (Requejo, 1994), which corresponds to Rank(S) $c a .13$ in NZ coals (Suggate and Boudou, 1993).

Significant thermal destruction of biomarkers is unlikely at $\operatorname{Rank}(\mathbf{S})<13$, so isomerism may play a role in initial bitumen, which is retained within coal for considerable time at elevated temperatures prior to expulsion. At $\operatorname{Rank}(\mathbf{S})>13$ thermal stability appears to become the dominant factor, in view of the rapid increase in relative abundance of neohopanes and diahopanes (Fig. 7). This is because: (1) kerogen is not thought to be important in the origin of $27 \mathrm{~N}$ (Farrimond et al., 1996), (2) predicted thermal stability increases in the order $17 \alpha(\mathrm{H})$-hopanes $<18 \alpha(\mathrm{H})$-neohopanes $<17 \alpha(\mathrm{H})$ - 
diahopanes (Moldowan et al.. 1991 and (3) hopanes are mainly generated over the Rank(S) range 13-14, from the relative abundance of neo/ diahopanes in NZ coal-sourced oils (Fig. 7). Once expulsion commences, it is anticipated that the residence time of biomarkers in bitumen within coal is short, so there is little time for isomerism to occur before migration results in a significant decrease in temperature. Consequently, the apparent decline in maturity parameter values between Rank(S) 13 and 14 could be at least partiy attributable to a lower apparent maturity for freshly evolved biomarkers than for those in the initial bitumen, due to steric hindrance of isomerism in kerogen-bound biomarkers (Michaelis et al. 1990; Peters et al.. 1990).

The variation in hopane $\mathrm{C}$ number with coal rank in $\mathrm{NZ}$ petroleum exploration wells has been known for some time (Johnston et al., 1988; Collier and Johnston, 1991). It has also recently been reported, along with high-maturity hopane:moretane reversals, for a series of Eocene coals from the West Coast region of NZ (Newman et al., 1997), and was attributed to the effects of oil expulsion commencing at the high-volatile/medium-volatile bituminous coal boundary $[\operatorname{Rank}(\mathrm{S}) c a, 13.5$; $\mathrm{cf}$. Suggate and Boudou. 1993]. The data are consistent with the generation/thermal stability model proposed above (Killops, 1998).

A ternary plot of $17 \alpha(\mathrm{H})$-hopane $\mathrm{C}$-number distribution is presented in Fig. 8 for Tara coals and for coals from various wells in Taranaki Basin. Approximate positions of isoRank(S) lines are

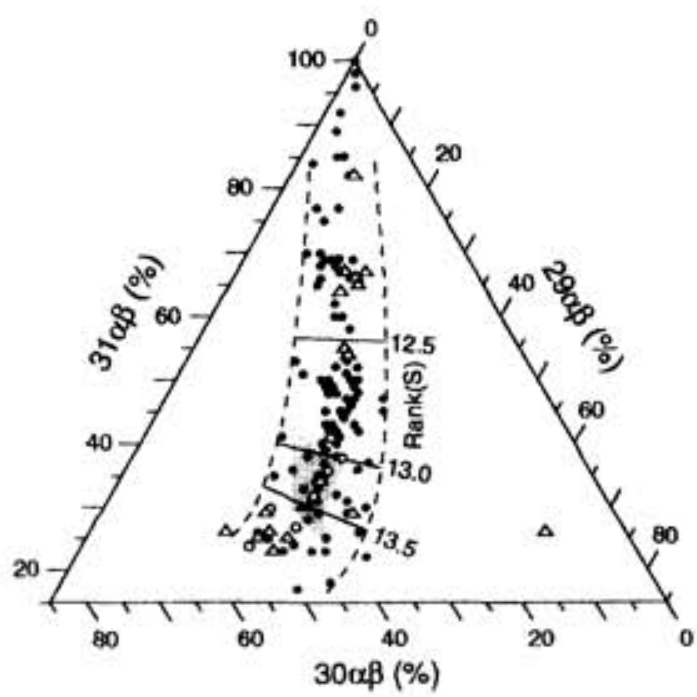

Fig. 8. Ternary plot of the relative abundance of $\mathrm{C}_{29}, \mathrm{C}_{30}$ and $\mathrm{C}_{31}(22 \mathrm{~S}+22 \mathrm{R}) 17 \alpha(\mathrm{H})$-hopanes in coals from varjous wells. (Based on $\mathrm{m} / \mathrm{z} 191$ response. $\Delta$ - Tara coals; $\mathrm{O}=$ Toko coals: $\mathbf{0}$ = other Taranaki Basin coals. Halftoning = province of coal-sourced oils in Taranaki Basin. Additional data after Crisp, 1986.) shown, but there is some spread in data and so the boundaries are indicative only. At Rank(S) $<12.5$ the data spread is too pronounced to permit reliable correlation of Rank(S) and hopane distributions. The majority of NZ coal-sourced oils plot in the Rank(S) range 13.0-13.5 (half-toning. Fig. 8). The trend for coal samples in Fig. 8 is approximately linear with increasing maturity up to the proposed onset of oil expulsion, and indicates that $29 \alpha \beta$ and $30 \alpha \beta$ are generated from kerogen in similar amounts, and greater than $3 i \alpha \beta$, up to $\operatorname{Rank(S)} c a$. 13 , resulting in a dilution of the pronounced $31 \alpha \beta$ contribution in initial bitumen. A similar trend of decreasing $3 \mid \alpha \beta$, and at higher maturity a relative increase in $30 \alpha \beta$, has been noted by Farrimond $e t$ al. (1996). The apparent relative increase in $30 \alpha \beta$ above Rank(S) $c a .13$ could reflect changes in the distribution of generated hopanes and/or differences in thermal degradation rates. The trend does not appear to be affected by whether coals expel oil (e.g. Tara) or not (e.g. Toko, as discussed below). However, it may be due at least partly to the effect of unidentified co-eluting components during GCMS analysis, which are initially in relatively low abundance but are of higher thermally stability than the regular hopanes (cf. neo/diahopanes).

\section{Factors controlling oil expulsion}

As can be seen from Fig. 5(d), S1 + S2 accounts for only $c a .60 \%$ of volatile matter during oil expulsion, so it is potentially dangerous to ignore the influence on expulsion of fluids other than hydrocarbons. The generally smooth decline in various O-containing groups in Fig. 4(a) is the result of fitting linear trends to available data (Killops et al., 1996). Data from ${ }^{13} \mathrm{C}$ NMR studies of Tara coals (Fig. 3(b); Dickinson et al., 1991) generally appear to corroborate these trends. However, the picture is complicated by the potential interconversion of some O-groups, such as the demethylation of methoxy to yield phenolic groups. There is a rapid decline in atomic $\mathrm{O} / \mathrm{C}$ at $\operatorname{Rank}(\mathrm{S}) c a .12$ in Tara coals, without an apparent corresponding anomaly in the $\mathrm{O}$-bound $\mathrm{C}$ content, as measured by ${ }^{13} \mathrm{C}$ NMR (Fig. 3(c)). Prior to the rapid decline in $\mathrm{O} / \mathrm{C}$, the atomic ratio appears to have been decreasing at about twice the rate of $\mathrm{O}$-bound $\mathrm{C}$, which may reflect the loss of $\mathrm{O}$ predominantly as $\mathrm{CO}_{2}$. It has been suggested that during diagenesis $\mathrm{C}$ is lost mainly as $\mathrm{CO}_{2}$, which would require $\mathrm{O}$-containing groups other than carboxyl to be involved in disproportionation reactions (Boudou et al., 1984). However. if water is evolved in appreciable amounts, a contribution from products with a lower O:C ratio than $\mathrm{CO}_{2}$ is needed. The steeper decline in $\mathrm{O} / \mathrm{C}$ at $\operatorname{Rank}(\mathrm{S})$ ca. 12 may represent a major phase of $\mathrm{CO}_{2}$ generation, which could contribute to over-pressuring and oil expulsion (Killops et al., 1996). 
Chemical adsorption is considered an important control on the expulsion of oil from coals (Hunt, 1991; Sandvik et al., 1992; Pepper and Corvi, 1995b) and may vary with microlithotype (Stout, 1994). A general oil expulsion threshold value of $100 \mathrm{mg} \mathrm{HC} / \mathrm{g}$ TOC for BI has been suggested (Pepper and Corvi, 1995b), but it appears rather high for NZ coals (Figs 7 and 9; Sandvik et al., 1992), although values up to $80 \mathrm{mg} \mathrm{HC} / \mathrm{g}$ TOC have been recorded for the Walloon coal measures of Australia (Khorasani and Michelsen, 1991). However, the S1 pyrolysis may not remove all the bitumen, particularly that in closed pores (Radke et al.. 1990; Littke and Leythaeuser, 1993). It is possible that the effects of adsorption are modified by those of porosity (Hunt, 1991), but there are problems of obtaining meaningful porosity data for insitu coals (e.g. Killops et al., 1996). Coal porosity is probably no more than $c a .5 \%$ at $4-5 \mathrm{~km}$ depth, so if $1 \mathrm{~g} \mathrm{C}_{\text {org }}$ is equivalent to $c a .1 .5 \mathrm{~g}$ coal occupying ca. $1.15 \mathrm{~cm}^{3}$, pore volume could total $0.06 \mathrm{~cm}^{3}$ and accommodate up to $75 \mathrm{mg}$ oil (in the absence of water). In practice, it is difficult to distinguish between petroleum that is unbound in pores and that chemically adsorbed (Pepper and Corvi, 1995b). The fact that BI does not decrease significantly upon onset of expulsion argues against mass draining of over-pressured pores and for dominance of adsorption, with gradual release of hydrocarbons once adsorption sites have been saturated. In contrast, the relatively rapid decrease in atomic $\mathrm{H} / \mathrm{C}$ ratio and increase in $f_{a}^{\prime}$ (Fig. 7) are consistent with a pulse of paraffin expulsion.

Although paraffinic hydrocarbons have the lowest adsorption affinities among petroleum components, the degree of saturation of adsorption sites, particularly by aromatic hydrocarbons and NSO compounds, prior to the main phase of oil generation may be important in determining the expulsion thresholds of waxy oils (Horsfield et al.. 1988; Noble et al., 1991; Sandvik et al., 1992; Pepper and Corvi, 1995b). So the amount of initial bitumen, which tends to be aromatic and NSO-rich (Katz et al., 1991), is likely to be important. The sat:aro ratio for bitumen extracted from Tara coals is $c a$. 0.5 in immature samples and tends towards a maximum of $\mathrm{ca} .0 .8$ at higher maturity (Fig. 7). If this is simply the effect of diluting initial bitumen with thermally-generated paraffins, expulsion requires $c a$. $60 \%$ increase in bitumen content, which is similar to the observed increase in BI (from ca. 15 to $25 \mathrm{mg} \mathrm{HC} / \mathrm{g}$ TOC; Fig. 7). This is a small amount, and could suggest that only a little PM is necessary in some coals for paraffinic oil to be expelied. However, it ignores the potential generation (and adsorption) of aromatic hydrocarbons (mainly methylated naphthalenes and phenanthrenes in NZ oils), which would raise the required amount of petroleum to be generated. It is not certain that expelled oil has a sat:aro ratio approaching unity, because oils in Taranaki Basin have higher values, even when secondary migration distances are rela-

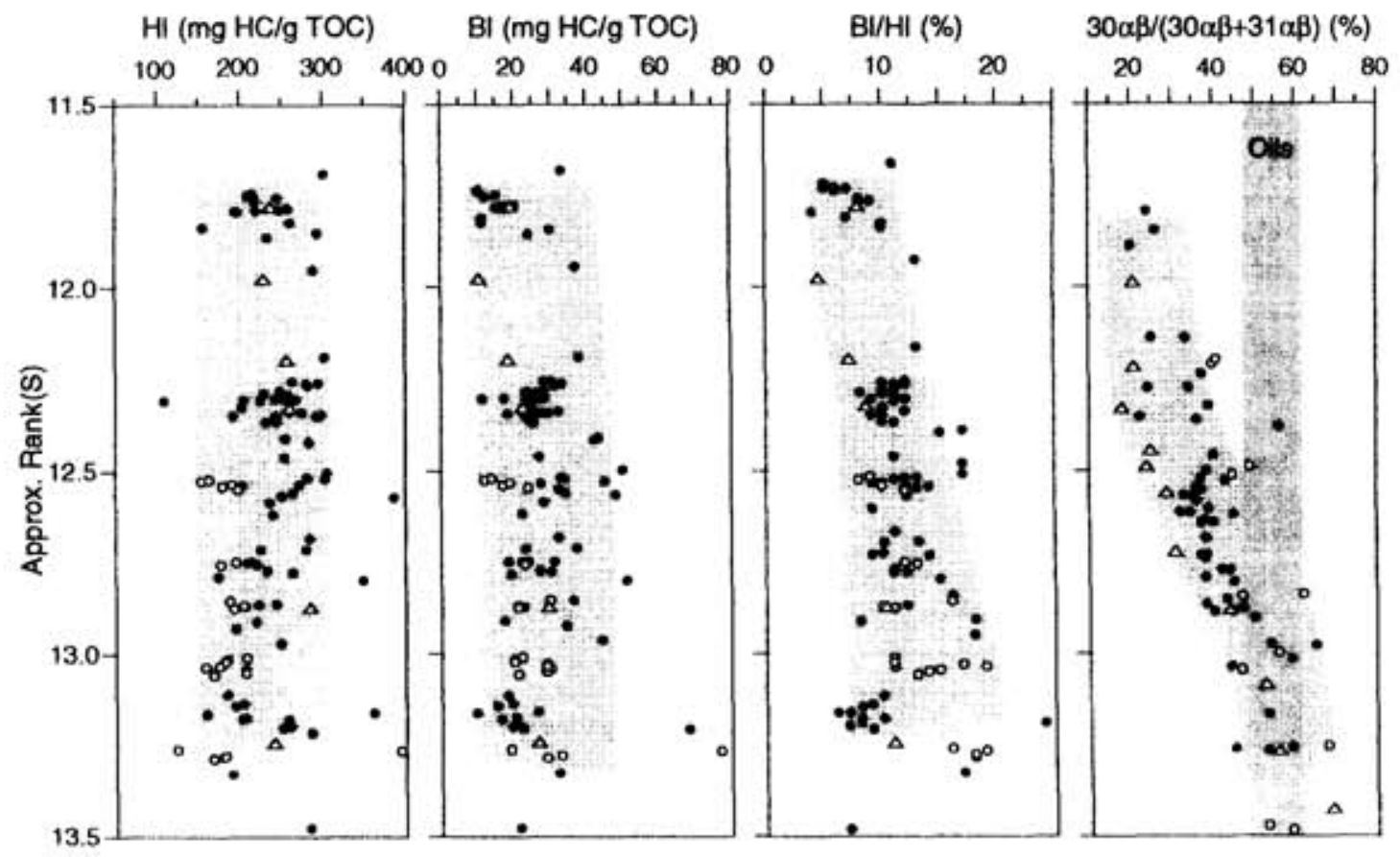

Fig. 9. Rank-related trends in Rock-Eval and hopane data for coals from various wells in Taranaki Basin. $(\Delta=$ Tara coals; $O=$ Toko coals; $=$ other Taranaki Basin coals. Rock-Eval data for wells in Taranaki Basin after Crisp. 1986. Additional hopane data after Crisp. 1986: Johnston et al. 1988: Collier and Johnston. 1991.) 
tively short (e.g. Killops et al., 1994). It is also not clear if the aromatics in Tara coal bitumens represent adsorbed components from either the initial bitumen or early-generated hydrocarbons (mainly from lignin and tannins), or whether they are a consequence of continuing generation (and expulsion) of aromatics throughout the oil window. Results from Mahakam coals suggest that aromatics (mainly methylated benzenes and naphthalenes) are generated carly, before paraffins (Bjoroy et al., 1988), and that preferential adsorption of aromatics from initial bitumen may account for the observed sat:aro ratios.

If the changes observed in atomic $\mathrm{H} / \mathrm{C}$ ratio and ${ }^{13} \mathrm{C}$ NMR parameter $f_{\mathrm{a}}^{\prime}$ at $\operatorname{Rank}(\mathrm{S}) \mathrm{ca} .13$ (Fig. 7) are entirely due to expulsion of paraffins, the quantities involved are $c a .35$ and $170 \mathrm{mg} \mathrm{HC} / \mathrm{g} \mathrm{C}_{\text {org }}$, respectively (based on $\mathrm{C}_{17} \mathrm{H}_{36}$ ). Both values would increase if aromatics were expelled in addition to paraffins. The atomic $\mathrm{H} / \mathrm{C}$ value is consistent with $\mathrm{BI}$ and sat:aro predictions, but the NMR value seems unrealistically high and is likely to be an overestimation in view of the relative suppression of the aromatic signal in the CPMAS method (e.g. Maroto-Valer et al., 1998).

To examine whether Rock-Eval data can be used to predict oil expulsion, analysis was undertaken of coal data from a number of exploration wells in Taranaki Basin. Data were restricted to one source (Crisp. 1986) to avoid inter-laboratory variations, and the trends in the Rank(S) range of interest are shown in Fig. 9. Unfortunately, the Rock-Eval data cannot be presented as the preferred $\mathrm{C}$-content values, because the factor used to convert $\mathrm{SI}$ and S2 to the reported equivalent hydrocarbon-content values is unknown. In general, the expected trends in Rock-Eval data are observed, but there is considerable data spread, attributable to differences in coal composition within and between wells. The hopane parameter $30 x \beta /(30 \alpha \beta+31 \alpha \beta)$ also exhibits a spread of data, influenced by variations in both the bacterial activity affecting initial bitumen and the degree of bacteriohopanoid incorporation into kerogen. Coals from Toko-1 well may be close to the limiting potential for oil expulsion, because $\mathrm{HI}$ is generally low but $\mathrm{BI} / \mathrm{HI}$ is high and still increasing at Rank(S) 13.5 (Fig. 9), suggesting expulsion has yet to occur. $\mathrm{HI}_{\max }$ in the Toko coals is $\mathrm{ca}$. $200 \mathrm{mg} \mathrm{HC} / \mathrm{g}$ TOC, which has been proposed as a general threshold value for oil expulsion from coals (Pepper and Corvi, 1995b). In comparison, $\mathrm{HI}$ is high for Tara coals, whereas $\mathrm{BI} / \mathrm{HI}$ values are low and constant above Rank(S) 13 (Fig. 9) because only a small proportion of PM has to be converted to exceed the oil-expulsion threshold. Comparison of $\mathrm{BI}$ (equivalent to $\mathrm{C}_{\text {bitumen }} / \mathrm{C}_{\mathrm{PM}}+$ lignin) and $\mathrm{BI} /$ $\mathrm{HI}$ (equivalent to $\mathrm{C}_{\text {bitumen }} / \mathrm{C}_{\mathrm{PM}}$ ) trends suggest that the adsorption capacities of PM and lignin are similar.
It would be convenient if the routinely obtained Rock-Eval data could be used to model the expelled amount of paraffins. The main problem is determining whether generation of aromatics and NSO compounds has to be included, or whether a reasonably accurate picture can be obtained from consideration of paraffinic components only. The following simple model is based upon only the paraffinic component. Previous models have considered coals as one member of a range of kerogen types and corresponding expulsion thresholds were based on bulk petroleum (e.g. Pepper and Corvi, 1995b).

\section{Paraffinic hydrocarbon potential and $\mathrm{HI}_{\text {mas }}$}

It may be possible to calculate the PM contribution to total $\mathrm{HI}\left(\mathrm{HI}_{\mathrm{PM}}\right)$ for coals lying above the lignin-evolution line in Fig. 1, if the lignin contribution to $\mathrm{HI}\left(\mathrm{HI}_{\text {lignin }}\right)$ is known, because we can assume $\mathrm{HI}=\mathrm{HI}_{\mathrm{PM}}+\mathrm{HI}_{\text {lignin }}$ for such coals. For Tara coals. $\mathrm{HI}_{\max }$ is ca. $250 \mathrm{mg} \mathrm{HC} / \mathrm{g}$ TOC, $\mathrm{C}_{\mathrm{PM}}$ is predicted to be $\mathrm{ca} .8 .5 \%$ from Fig. $\mathrm{I}(\mathrm{b})$, so $\mathrm{HI}_{\mathrm{PM}}$ should be $99 \mathrm{mg} \mathrm{HC} / \mathrm{g}$ TOC. The $\mathrm{Hl}_{\text {lignin }}$ contribution to $\mathrm{HI}_{\max }$ is, therefore, $151 \mathrm{mg} \mathrm{HC} / \mathrm{g}$ TOC for $91.5 \% \mathrm{C}_{\text {lignin, }}$ so pure lignin should have an $\mathrm{HI}_{\max }$ of $165 \mathrm{mg} \mathrm{HC} / \mathrm{g}$ TOC. For any vitrinite-rich coal for which $\mathrm{HI}_{\text {max }}$ can be measured or predicted using Fig. 6. $\mathrm{C}_{\mathrm{PM}} / \mathrm{C}_{\text {org }}=\left(\mathrm{HI}_{\max }-165\right) / 1002$, and $\mathrm{HI}_{\mathrm{PM}}=1167\left(\mathrm{HI}_{\max }-165\right) / 1002$.

The typical saturation value of $\mathrm{BI}$ at the onset of oil expulsion for NZ coals is $20-40 \mathrm{mg} \mathrm{HC} / \mathrm{g}$ TOC (Fig. 9: Sandvik et al., 1992). BI probably measures predominantly PM-derived hydrocarbons after oil expulsion begins, so for oil expulsion to occur $\mathrm{HI}_{\mathrm{PM}}$ must be $>20 \mathrm{mg} \mathrm{HC} / \mathrm{g}$ TOC. Alternatively. for oil expulsion to occur it appears $\mathrm{HI}_{\max }$ has to be $>200 \mathrm{mg} \mathrm{HC} / \mathrm{g}$ TOC, as discussed above for Toko coals, so $\mathrm{HI}_{\mathrm{PM}}$ must be $>40 \mathrm{mg} \mathrm{HC} / \mathrm{g}$ TOC $\left(\mathrm{C}_{\mathrm{PM}}: \mathrm{C}_{\text {lignin }} \mathrm{ca} .4: 96\right)$ according to the postulated relationship between $\mathrm{HI}_{\max }$ and $\mathrm{HI}_{\mathrm{PM}}$. From these estimates of limiting $\mathrm{HI}_{\mathrm{PM}}$ it is likely that only coals within the upper part of the NZ Coal Band and above (i.e, higher $\mathrm{H} / \mathrm{C}$ ratio, Fig, 1) will expel oil.

An expulsion threshold value for $\mathrm{HI}_{\mathrm{PM}}$ of $40 \mathrm{mg}$ $\mathrm{HC} / \mathrm{g}$ TOC is used to predict amounts of expelled paraffinic oil from the relationship between $\mathrm{HI}_{\text {max }}$ and $\mathrm{HI}_{\mathrm{PM}}$ for coals approximating to lignin-PM mixtures in Fig. 10. For coals capable of exceeding the saturation BI value. expulsion occurs over a limited Rank(S) range: between the onset of paraffinic oil generation at 12 and the onset of significant cracking to gas at $c a, 14.5$ (equivalent to an in-situ temperature of $c a .160^{\circ} \mathrm{C}$; Mackenzie and Quigley. 1988; Sandvik et al., 1992), as similarly proposed by Suggate and Boudou (1993).

A test of the accuracy of $\mathrm{HI}_{\mathrm{PM}}$ determination is shown in Fig. 11. The behaviour of $\mathrm{BI} / \mathrm{HI}$ PM vs $\mathrm{HI}_{\mathrm{PM}}$ can be predicted, as in Fig. 11(a) (inset). For this prediction, conditions are determined by the 


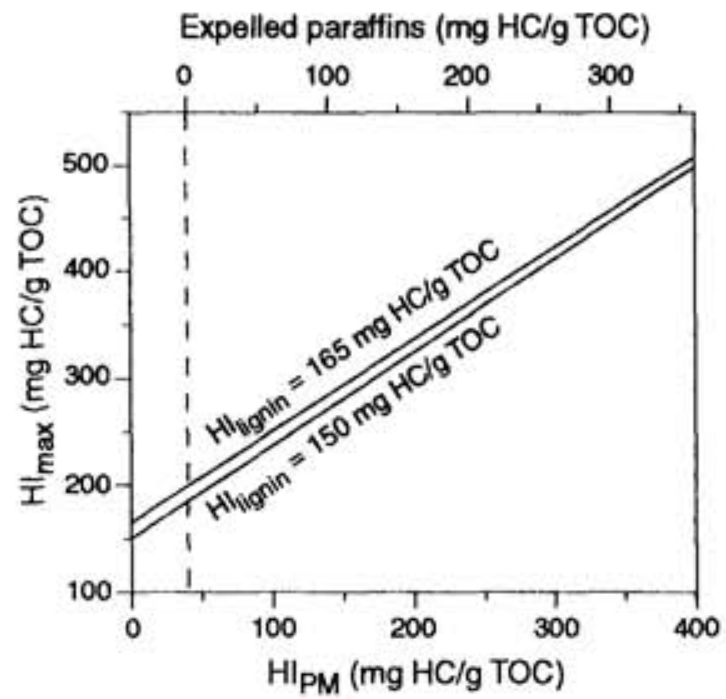

Fig. 10. Predicted polymethylene contribution to $\mathrm{HI}_{\max }$ and corresponding parafinic oil expulsion potential. (Based on an expulsion threshold $\mathrm{HI}_{\mathrm{PM}}$ value of $40 \mathrm{mg}$ $\mathrm{HC} / \mathrm{g}$ TOC for two pure lignin $\mathrm{HI}$ values of 150 and $165 \mathrm{mg} \mathrm{HC} / \mathrm{g}$ TOC.)

best fit to the coal data (Fig. 9): initial Bl is set at $10 \mathrm{mg} \mathrm{HC} / \mathrm{g}$ TOC and expulsion takes place when B1 reaches $40 \mathrm{mg} \mathrm{HC} / \mathrm{g}$ TOC (i.e. $30 \mathrm{mg} \mathrm{HC} / \mathrm{g}$ TOC of $\mathrm{HI}_{\mathrm{PM}}$ has been converted to oil). All coals initially start on the lower margin of the shaded area and follow evolutionary paths shown by the arrowed lines. A break in gradient of the coal trends occurs at the onset of expulsion, whereupon the trends follow the upper margin of the shaded area until oil cracking becomes significant. All coals fall within the shaded area in the absence of significant oil cracking (which causes $\mathrm{BI} / \mathrm{HI}_{\mathrm{PM}}$ to decrease rapidly). $B I / H_{P M}$ tends to infinity as $\mathrm{HI}_{P M}$ approaches zero, and to a common saturation threshold value as $\mathrm{HI}_{\mathrm{PM}}$ becomes large. The same $\mathrm{HI}$ data for Taranaki Basin and Tara coals used in Fig. 9 are converted to $\mathrm{HI}_{\mathrm{PM}}$ values in Fig. 11 (a). In order to calculate $\mathrm{HI}_{\mathrm{PM}}$ values, it is assumed that over the $\operatorname{Rank}(\mathrm{S})$ range 11.5-13.5 pure lignin has an almost constant $\mathrm{HI}$ value of $150 \mathrm{mg} \mathrm{HC} / \mathrm{g}$ TOC (which provides the best fit for the Taranaki coal data) and that the $\mathrm{HI}$ value for a given coal is also effectively constant [i.e. equivalent to $\mathrm{HI}_{\max }$; so $\left.\mathrm{HI}_{\mathrm{PM}}=1167\left(\mathrm{HI}_{\max }-150\right) / 1017\right]$. All but 2 of the 108 coals follow the expected trend, suggesting the approximations involved and the underlying model of $\mathrm{HI}_{\mathrm{PM}}$ prediction are reasonable.

The expulsion threshold used appears reasonable for the Taranaki Basin data, and suggests that most Toko coals have marginal expellable oil potential (Fig. 11(a)). Tara coals lie below the upper margin of the predicted envelope, although they expel oil by $\operatorname{Rank}(\mathbf{S})$ 13, which suggests that the expulsion limit is lower for these coals. This may be caused by differences in analytical procedures between the two sample sets and/or varying accuracy of assumed $\mathrm{C}$ content of $\mathrm{S} 1$ and $\mathrm{S} 2$ for the samples (including calibration standards). Although the model in Fig. II(a) requires conversion of only $30 \mathrm{mg} \mathrm{HC} / \mathrm{g}$ TOC for oil expulsion to occur, for coals of marginal oil potential the $\mathrm{HI}_{\mathrm{PM}}$ limit may be nearer $40 \mathrm{mg} \mathrm{HC} / \mathrm{g} \mathrm{TOC}$, as suggested above, because the oil expulsion threshold moves towards higher maturity with decreasing PM content and expulsion may not occur before the remaining PM is cracked to very short-chain components (i.e. gases at surface conditions).

An examination of gas generation in relation to the PM-lignin model can be made using gas:oil generation indices $\left[\mathrm{GOGI}=\left(\mathrm{C}_{1}-\mathrm{C}_{5}\right) /\left(\mathrm{C}_{5}-\mathrm{C}_{36}\right)\right]$ for the Taranaki coals (Crisp, 1986). Most coals in a plot of GOGI values vs modelled $\mathrm{HI}_{\mathrm{PM}}$ (Fig. II(b)) follow a general trend of decreasing proportions of gas with increasing $\mathrm{HI}_{\mathrm{PM}}$, as expected. Using a value of $30 \mathrm{mg} \mathrm{CH} / \mathrm{g}$ TOC for pure lignin under open pyrolysis conditions (Béhar et al., 1997b) and assuming complete conversion of PM to oil, the $0 \%$ contour shows the predicted relationship between GOGI and $\mathrm{HI}_{\mathrm{PM}}$. Most coals deviate from this trend towards higher GOGI values. A cioser fit is observed if $10 \%$ of PM is allowed to crack to gas $\left(C_{1}-C_{5}\right)$, and most samples fall between 0 and $20 \%$ PM cracking. Such minor direct gas formation from PM would not significantly affect the modelled behaviour in Figs 10 and 1I(a). The GOGI values represent open-system laboratory pyrolysis, so they are likely to underestimate expelled gas:oil ratios for the most PM-lean coals (with the lowest oilexpulsion efficiencies) in real petroleum systems.

\section{Kinetic modelling of hydrocarbon generation}

The uncertainties in the factors controlling expulsion of oil from coal are no more significant than those associated with prediction of hydrocarbon generation rates. As well as general reservations about whether rapid pyrolysis in open or closed systems accurately simulates the types of reactions that occur under geological heating rates (e.g. Landais and Monthioux, 1988; Ritter et al., 1995), there are some specific problems with coals. Approximating the kinetics of kerogen degradation by a single $\mathrm{A}$ value for a relatively restricted range of $E_{\text {act }}$ values appears to permit reasonable extrapolation of laboratory heating rates to geological thermal regimes for kerogens dominated by one hydrocarbon-generating component, but not for coals with their very broad $E_{\text {uct }}$ ranges (Schenck and Horsfield, 1995; Béhar et al.. 1997b). For example, meaningful gas generation kinetics were not obtained from the oilprone coals of organofacies DE of Pepper and Corvi (1995a). A more accurate representation of coals might be obtained by treating separately the generation of paraffinic oil from PM, aromatic oil from lignin and tannins, naphthenic and aromatic 

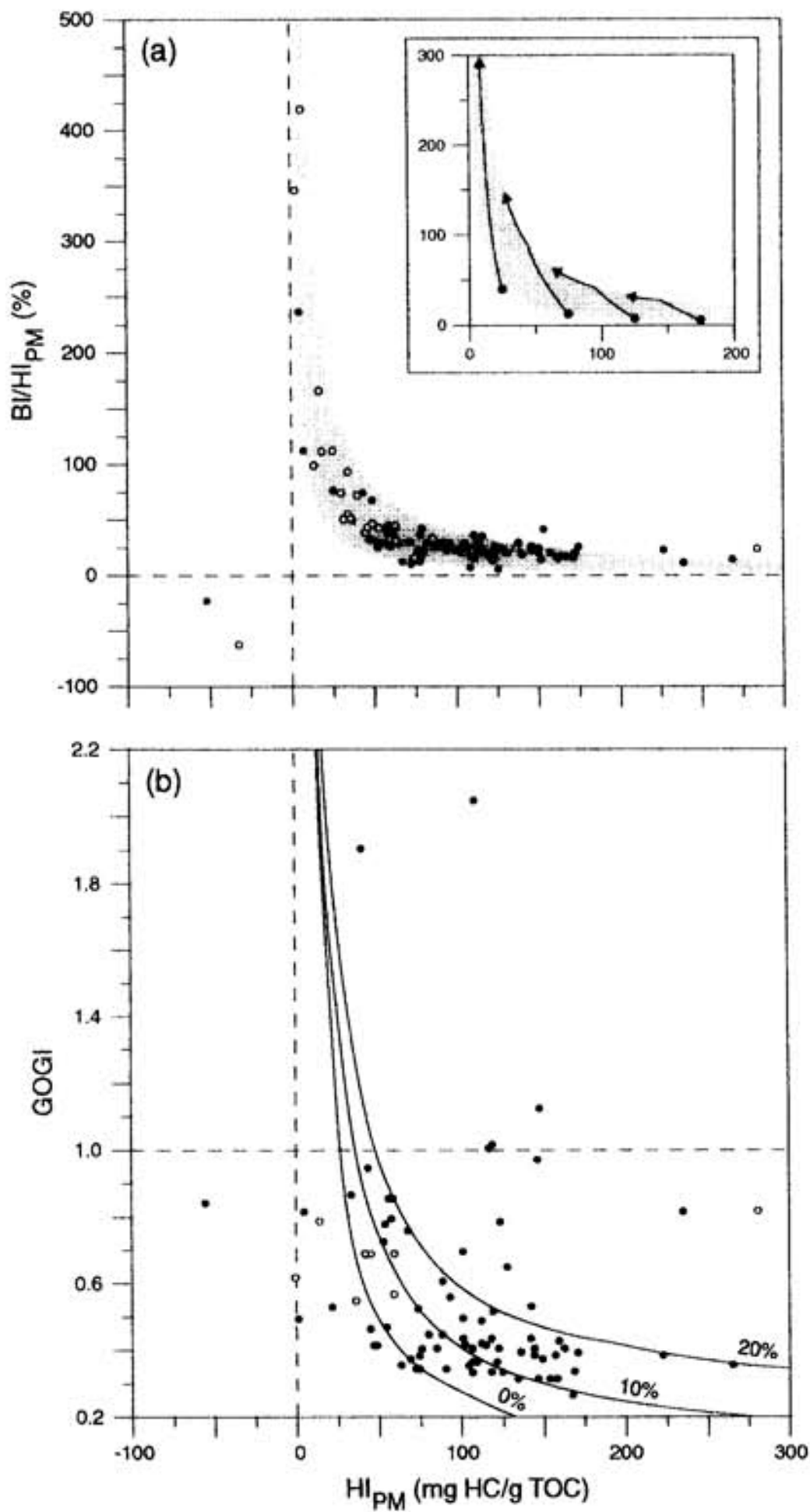

Fig. 11. Polymethylene contribution to $\mathrm{HI}$ and hydrocarbon distributions. (a) $\mathrm{BI} / \mathrm{HI}_{\mathrm{PM}}$ vs $\mathrm{HI} \mathrm{PM}$ for coals from Tara-1 and various wells in Taranaki Basin in relation to predicted trends in inset (prediction for initial $\mathrm{BI}=10 \mathrm{mg} \mathrm{HC} / \mathrm{g}$ TOC and expulsion at $\mathrm{BI}=40 \mathrm{mg} \mathrm{HC} / \mathrm{g} \mathrm{TOC}$; examples of coal evolution trends shown by arrowed lines). (b) Predicted and measured GOGI vs $\mathrm{HI}_{\mathrm{PM}}\left[\mathrm{GOGI}=\left(\mathrm{C}_{1}-\mathrm{C}_{5}\right)\right.$ ] $\left(C_{5}-C_{16}\right)$ wt. ratio from pyrolysis GC: predicted contours based on pure lignin contribution of $30 \mathrm{mg}$ $\mathrm{CH}_{4} / \mathrm{g}$ TOC and 0,10 or $20 \%$ cracking to gas of PM component). ( $\triangle=$ Tara coals; $\mathrm{O}-$ Toko coals; - other Taranaki Basin coals. Taranaki Basin HI and GOGI data after Crisp, 1986.) 
oil from resins, and dry gas from lignin. Even so, some of these reactions would probably not be characterised by a discrete $\mathrm{A}$ value and narrow $E_{\text {act }}$ distribution, due to the variety of chemical bonds involved.

The cracking of PM should be characterised by a very small range of $E_{\text {ate }}$, similar to that for secondary cracking of $n$-alkanes, because there is little change in $\mathrm{C}-\mathrm{C}$ bond energy with position in a polymethylene chain. The balance between long-chain. liquid products and short-chain, gaseous products is, therefore, primarily determined by probability: as the cracking reactions progress, relatively more short-chain components will be randomly produced because the proportion of shortened polymethylene chains increases. Above $c a .160^{\circ} \mathrm{C}$ it seems that the major products are methane and other short-chain alkanes (Mackenzie and Quigley, 1988; Sandvik et al., 1992).

PM cracking is apparently reflected in the sharp maximum in the $E_{\text {act }}$ frequency distribution for the group E kerogen of Tegelaar and Noble (1994) at $55-57 \mathrm{kcal} / \mathrm{mol}\left(A=6.5 \times 10^{14} \mathrm{~s}^{-1}\right)$. This kerogen group generates abundant $n$-alkane/alkene pairs upon pyrolysis, and is considered to contribute to NZ and similar coals, together with group G kerogen (Tegelaar and Noble, 1994). The latter is thought to represent pure vitrinite, yielding mainly lignin components upon pyrolysis, but it exhibits considerable variation in generation characteristics. It has a broad $E_{\text {act }}$ distribution $(53-63 \mathrm{kcal} / \mathrm{mol}$, $A=9.5 \times 10^{1.4} \mathrm{~s}^{-1}$ ), but still with a maximum at $56-57 \mathrm{kcal} / \mathrm{mol}$ consistent with a slight PM contribution. Attempts have been made to obtain kinetic parameters for the individual submacerals cutinite. sporinite, suberinite and alginite (Michelsen and Khorasani. 1995). Cutinite was reported to yield a relatively broad $E_{a c 1}$ distribution $(43-64 \mathrm{kcal} / \mathrm{mol}$. $A=3.5 \times 10^{14} \mathrm{~s}^{-1}$ ), with a maximum at $53-54 \mathrm{kcal} /$ mol. compared to the smaller range with a maximum at $50 \mathrm{kcal} / \mathrm{mol}$ for suberinite. The broad cutinite distribution suggests a variety of cleavage reactions are involved.

The effects of varying PM and lignin contributions on the kinetic parameters obtained from Pyromat anatysis of total (i.e. undifferentiated) pyrolysate, using KINETICS optimisation software, can be seen in Fig. 12(a) for Eocene coals $\mathrm{MCl}$ and $\mathrm{MC} 2$ from the Maramarua coalfield, NZ. Sample $\mathrm{MCl}$ appears to be virtually pure lignin, whereas $\mathrm{MC} 2$ contains hydrogen-rich material, based on their positions in Fig. 1(b). Although MC2 contains abundant liptinite, PM appears the major component on the basis of predominant, characteristic $n$-alkane/alkene pairs upon pyrolysis-GC analysis. Therefore, the $E_{\text {act }}$ spike at $53 \mathrm{kcal} / \mathrm{mol}$ $\left(A=8.8 \times 10^{13} \mathrm{~s}^{-1}\right)$ in $\mathrm{MC} 2$ probably reflects PM contribution. A similar spike is absent from $\mathrm{M} / 1 \mathrm{~L}$. although there are some minor contributions from n-alkanes/alkenes upon pyrolysis-GC analysis, testifying to the difficulty of obtaining vitrinite completely free of PM. Representative coals from exploration wells in Taranaki Basin exhibit $E_{\text {act }}$ distributions that fall between the extremes of the two Maramarua coals.

Transformation curves, representing the rate of conversion of initial petroleum potential (HI) vs temperature at a heating rate of $3^{\circ} \mathrm{C} / \mathrm{Ma}$, are shown in Fig. 12(b) for the Maramarua coals, together with Eocene (MK1) and Late Cretaceous (Mu4) coals of $\operatorname{Rank}(\mathrm{S})$ 12.0-12.5 from exploration wells in Taranaki Basin. The transformation curves for $\mathrm{MK1}$ and Mu4 are of similar shape to $\mathrm{MC2}$, but
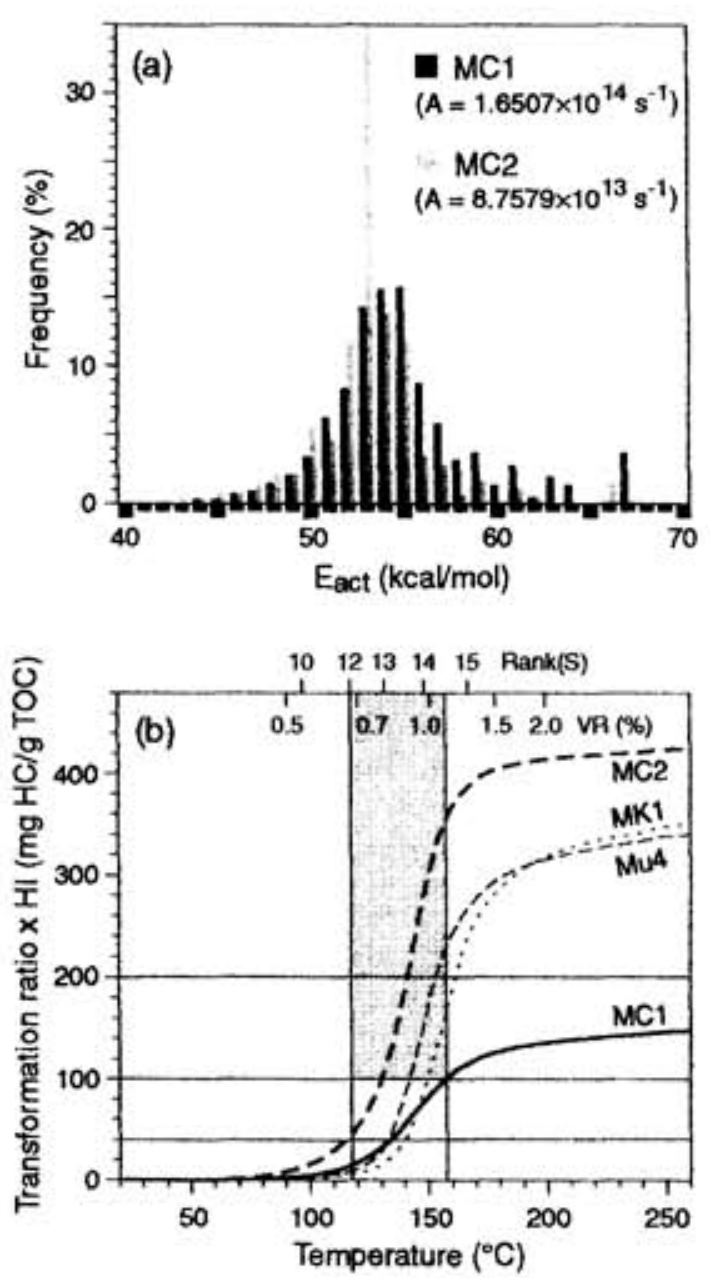

Fig. 12. Kinetic data for some NZ coals from open pyrolysis. (a) Optimised $E_{\text {act }}$ and $\mathrm{A}$ values for total pyrolysates from two Maramarua coals ( $\mathrm{MCl}$ and $\mathrm{MC2}$ ). (b) Petroleum generation profiles derived from data in (a). based on a uniform heating rate of $3 \mathrm{C} / \mathrm{Ma}$. $\left(\mathrm{VR}=\right.$ vitrinite reflectance modelied by Easy $\% R_{\mathrm{o}}$ (Sweeney and Burnham, 1990) and corresponding Rank(S) scale derived from the empirical relationship $\operatorname{Rank}(\mathrm{S})=\left(17.87-3.25 / \mathrm{VR}-0.5 / \mathrm{VR}^{2}\right)$. Coal samples as in (a) together with an Eocene coal from McKee-1 well and a Late Cretaceous coal from Maui-4 well. both in Taranaki Basin. Half-tone box shows likely window of oilexpulsion.) 
shifted to slightly higher temperature, because of their higher maturity. The steepness of the main part of the curve reflects the $E_{\text {sct }}$ spike due to paraffinic oil generation, hence the shallower gradient for $\mathrm{MCl}$. It is possible to define broad limits for oil expulsion on the plots of $\mathrm{HI}$ conversion. BI values are lower than converted $\mathrm{HI}$ values, even in the absence of expuision. because of the restricted range of pyrolysis products measured by S1. So if $\mathrm{BI}$ is ca. $40 \mathrm{mg} \mathrm{HC} / \mathrm{g} \mathrm{TOC}$ at the onset of oil expulsion, converted $\mathrm{HI}_{\max }$ must be $\geq 40$ and probably nearer $100 \mathrm{mg} \mathrm{HC} / \mathrm{g}$ TOC. If the onset of expulsion corresponds to $\mathrm{HI}_{\max }=200 \mathrm{mg} \mathrm{HC} / \mathrm{g}$ TOC. converted $\mathrm{HI}$ is $<200 \mathrm{mg} \mathrm{HC} / \mathrm{g}$ TOC because some gas potential must be present. So the onset of oil expulsion probably begins somewhere between conversion of 100 and $200 \mathrm{mg} \mathrm{HC} / \mathrm{g}$ TOC. The temperature limitations on generation of paraffinic oil correspond to $\operatorname{Rank}(\mathrm{S})$ values of 12 (onset of generation) and 14.5 (upper stability limit). So overall. expulsion is likely to occur only within the halftone box in Fig. 12(b). The transformation curves for the Maramarua and Taranaki Basin coals (Fig. 12(b)) are broadly consistent with this picture. However, it is not clear how accurately the kinetics model the generation of paraffinic oil. As a first approximation. it may be sufficient to model PM degradation alone.

\section{SUMMARY AND CONCLUSIONS}

It is possible to estimate the paraffinic oil potential of immature coals containing negligible fusinitic material and resins, based on a simple compositional model of lignin and polymethylene. The proportion of $\mathrm{C}$ present as $\mathrm{PM}$ in such a mixture can be determined from a Van Krevelen diagram if a discrete lignin evolution trend can be identified. It is proposed that the base of the NZ Coal Band defines this lignin trend. $\mathrm{HI}_{\mathrm{PM}}$ is then obtained by multiplying $\mathrm{C}_{\mathrm{PM}} / \mathrm{C}_{\text {org }}$ by the $\mathrm{HI}$ of pure $\mathrm{PM}$ (1167 $\mathrm{mg} \mathrm{HC}_{\mathrm{g} \mathrm{C}} \mathrm{C}_{\text {org }}$ ). The NZ Coal Band spans a $\mathrm{C}_{\mathrm{PM}} / \mathrm{C}_{\text {org }}$ range of $0-10 \%$, and Tara coals appear to comprise a fairly uniform suite with a $\mathrm{C}_{\mathrm{PM}} / \mathrm{C}_{\mathrm{org}}$ of $c a .8 .5 \%$.

Rock-Eval HI measurements are affected by an apparent suppression at low maturity, which is partly attributable to O-group suppression of the FID signal. Structural rearrangements within the closed coal-bitumen system also appear to affect $\mathrm{HI}$. $\mathrm{HI}_{\mathrm{PM}}$ should not be affected by O-group suppression and so should remain almost constant until PM cracking begins. $\mathrm{HI}$ reaches a maximum at $\operatorname{Rank}(\mathbf{S})$ 12-13, near the onset of oil generation. Various geochemical parameters suggest that, for Tara coals, paraffinic oil generation begins at $\operatorname{Rank}(\mathrm{S})$ 12, and expulsion starts at $\operatorname{Rank}(\mathrm{S}) 13$. Because oil cracking becomes dominant above
Rank(S) 14.5, the potential expulsion window corresponds to Rank(S) 12.0-14.5.

For the Taranaki Basin coals studied, pure lignin appears to have an $\mathrm{HI}$ of $c a .150 \mathrm{mg} \mathrm{HC} / \mathrm{g} \mathrm{TOC}$ at Rank(S) $c a .12$. A similar value was obtained from a Van Krevelen diagram for the Tara coals $(165 \mathrm{mg}$ $\mathrm{HC} / \mathrm{g} \mathrm{TOC}$ ). The $\mathrm{HI}_{\mathrm{PM}}$ value for any coal approximating to a lignin-PM mixture near $\operatorname{Rank}(\mathrm{S}) \quad 12$ can then be determined from its $\mathrm{HI}_{\max }$ value from the relationship $\mathrm{HI}_{\mathrm{PM}}=1167\left(\mathrm{HI}_{\max }-150\right) / 1017$ (or $\mathrm{HI}_{\mathrm{PM}}=1.15 \mathrm{HI}_{\max }-172$ ). Oil saturation thresholds at the onset of expulsion, as measured by BI, fall in the range $20-40 \mathrm{mg} \mathrm{HC} / \mathrm{g}$ TOC for the NZ coals analysed. Toko coals $\left(\mathrm{HI}_{\max } \mathrm{ca} .200 \mathrm{mg} \mathrm{HC} / \mathrm{g}\right.$ TOC) appear close to the minimum potential required for expulsion of paraffinic oil. A model of oil generation and expulsion can be constructed on the basis of $\mathrm{HI}_{\mathrm{PM}}$ values, a saturation threshold of $40 \mathrm{mg} \mathrm{HC} / \mathrm{g}$ TOC and an initial $\mathrm{Bl}$ of $10 \mathrm{mg} \mathrm{HC} / \mathrm{g}$ TOC. The variation of $\mathrm{BI} / \mathrm{HI}_{\mathrm{PM}}$ vs $\mathrm{HI}_{\mathrm{PM}}$ predicted by this model correlates well with data from Taranaki Basin coals, suggesting the basis of the model is reasonable. Similarly, the model appears capable of explaining general trends in GOGI values.

The variation in $\mathrm{HI}$ with rank suggests that any kinetic analysis that relies on FID detection of coal pyrolysate has to be treated with caution. Optimised kinetic data derived from total pyrolysate suggests that PM is represented by a narrow $E_{\text {act }}$ distribution towards the lower end of the wide range characteristic of bulk coals. The range of bond-types in such coals suggests that a single A value is unlikely to permit accurate kinetic modelling. As a first approximation, generation of paraffinic oil may be represented by PM degradation alone.

Acknowledgements - The authors thank Drs Lloyd Snowdon (Canadian Geological Survey), Dan Jarvie (Humble) and Eric Lafargue (IFP) for helpful discussions and IFP for Rock-Eval analyses. We are grateful to the NZ Foundation for Research. Science and Technology for funding this work (contract C05608). IGNS publication 1362.

\section{REFERENCES}

Alexander, R., Kralert, P. G. and Kagi, R. I. (1992) Kinetics and mechanism of the thermal decomposition of esters in sediments. Organic Geochemistry 19, 133 140.

Béhar, F. and Vandenbroucke, M. (1986) Représentation chimique de la structure des kérogènes et des asphaltènes en fonction de leur origine et de leur degré d"évolution. Revue de I'Institut Français du Pétrole 41, 173188.

Behar, F., Tang. Y, and Liu, J. (1997a) Comparison of rate constants for some molecular tracers generated during artificial maturation of kerogens: influence of kerogen type. Organic Geochemistry 26, 281-287.

Béhar, F., Vandenbroucke, M., Tang, Y., Marquis, F. and Espitalié, J. (1997b) Thermal cracking of kerogen in 
open and closed systems: determination of kinetic parameters and stoichiometric coefficients for oil and gas generation. Organic Geochemistry 26, 321-339.

Bishop. A. N. and Abbott, G. D. (1993) The interrelationship of biological marker maturity parameters and molecular yields during contact metamorphism. Geochimica et Cosmochimica Acta 57, 3661-3668.

Bjorøy, M., Hall, P. B., Leberg. R., McDermott, J. A. and Mills, N. (1988) Hydrocarbons from non-marine source rocks. Organic Geochemistry 13, 221-244.

Black, P. M. (1980) A reconnaissance survey of the petrology of New Zealand coals. New Zealand Energy Research and Development Committee Report 51.

Black. P. M. (1984) The Maramarua, Mokau And Kaitangata coalfields: petrology and some chemical and physical properties. New Zealand Energy Research and Development Committee Report, contract 3118.

Bostick. N. H. and Daws. T. A. (1994) Relationships between data from Rock-Eval pyrolysis and proximate, ultimate. petrographic. and physical analyses of 142 diverse US coal samples. Organic Geochemistry 21, 3549.

Boudou, J.-P.. Pelet, R. and Letolle, R. (1984) A model of the diagenetic evolution of coaly sedimentary organic matter. Geochimica et Cosmochimica Acta 48, 13571362

Boudou, J.-P., Espitalic,, J., Bimer, J. and Salbut, P. D. (1994) Oxygen groups and oil suppression during coal pyrolysis. Energy and Fuels 8, 972-977.

Clayton, J. L. and Bostick. N. H. (1986) Temperature effects on kerogen and on molecular and isotopic composition of organic matter in Pierre Shale near an igneous intrusion. Organic Geochemistry 10, 135-143.

Clayton, J, L., Rice, D. D. and Michael, G. E. (1991) Oilgenerating coals of the San Juan Basin. New Mexico and Colorado. USA. Organic Geochemistry 17, 735-742.

Collier, R. J. and Johnston, J. H. (1991) The identification of possible hydrocarbon source rocks, using biomarker geochemistry, in the Taranaki Basin. New Zealand. Journal of Southeast Asian Earth Sciences 5, 231-239.

Crisp, R. I. (1986) Geochemical Data for Eight Wells in the Taranaki Basin. New Zealand. Petroleum Report 1590. Ministry of Commerce, Wellington.

Curry, D. J., Emmett, J. K. and Hunt, J. W. (1994) Geochemistry of aliphatic-rich coals in the Cooper Basin. Australia and Taranaki Basin, New Zealand: implications for the occurrence of potentially oil-generative coals. In Coal and Coal-bearing Strata as Oil-prone Source Rocks? ed. A. C. Scott and A. J. Fleet, Geological Society Special Publication 77, pp. 149-182.

Czochanska, Z. Sheppard, C. M., Weston, R. J. and Woolhouse. A. D. (1987) A biological marker study of oils and sediments from the West Coast. South Island, New Zealand. New Zealand Journal of Geology and Geophysics 30, 1-17.

Dickinson, W. W. Newman, R. H. and Collen, J. D. (1991) Maturation parameters measured from ${ }^{13} \mathrm{C}$ NMR spectra compiled from Upper Cretaceous and Tertiary coals, New Zealand. Geology Board of Studies Publication 9. Victoria University of Wellington.

Durand, B. and Paratte, M. (1983) Oil potential of coals: a geochemical approach. In Petroleum Geochemistry and Exploration of Europe, ed. J. Brooks, Geological Saciety Special Publication 12. pp. 255-265.

Dzou, L. 1., Noble, R. A, and Senftle, J, T, (1995) Maturation effects on absolute biomarker concentration in a suite of coals and associated vitrinite concentrates. Organic Geochemistry 23, 681-697.

Farrimond, P., Bevan, J. C. and Bishop, A. N. (1996) Hopanoid hydrocarbon maturation by an igneous intrusion. Organic Geochemistry. 25, 149-164.
Hatcher, P. G. (1990) Chemical structural models for coalified wood (vitrinite) in low rank coal. Organic Geochemistry 16, 959-968.

Hatcher, P. G., Lerch, H. E. and Verheyen, T, V. (1989a) Organic geochemical studies of the transformation of gymnospermous xylem during peatification and coalifcation to subbituminous coal. International Journal of Coal Geology 13, 65-97.

Hatcher, P. G., Lerch, H. E., Bates, A. L. and Verheyen. T. V. (1989b) Solid-state ${ }^{13} \mathrm{C}$ nuclear magnetic resonance studies of coalified gymnosperm xylem tissue from Australian brown coals. Organic Geochemistry 14, 145155.

Hedges, J. J., Cowie, G. L., Ertel, J. R., Barbour, R. J. and Hatcher, P. G. (1985) Degradation of carbohydrates and lignins in buried woods. Geochimica et Cosmochimica Acta 49, 701-711.

Horsfield, B., Yordy, K. L. and Crelling, J. C. (1988) Determining the petroleum-generating potential of coal using organic geochemistry and organic petrology. Organic Geochemistry 13, 121-129.

Hunt, J. M. (1991) Generation of gas and oil from coal and other terrestrial organic matter. Organic Geochemistry 17, 673-680.

Isaksen, G. H., Curry, D. J., Yeakel, J. D. and Jenssen, A. 1. (1998) Controls on the oil and gas potential of humic coals. Organic Geochemistry, this volume.

Johnston. J. H., Collier, R. J. and Craig. J. T. (1988) Oitsource rock correlations in the Maui-4 oil exploration well, south Taranaki Basin. Energy Explorution and Exploitation 6, 233-247.

Jorgensen, A. D., Picel, K. C. and Stamoudis, V. C. (1990) Prediction of gas chromatography flame ionization detector response factors from molecular structures. Analytical Chemistry 62, 683-689.

Katz. B. J., Kelley, P. A., Royle, R. A. and Jorjorian, T. (1991) Hydrocarbon products of coals as revealed by pyrolysis-gas chromatography. Organic Geochemistry 17 . 711-722.

Khorasani, G. K. and Michelsen, J. K. (1991) Geological and laboratory evidence for early generation of large amounts of liquid hydrocarbons from suberinite and suberous components. Organic Geochemistry 17, 849863.

Killops, S. D. (1998) Comment on Newman ef al., 1997. Journal of Petroleum Geology 21, 233-234.

Killops, S. D., Woolhouse, A. D., Weston, R. J. and Cook, R. A. (1994) A geochemical appraisal of oil generation in the Taranaki Basin. New Zealand. AAPG Bulletin 78, 1560-1585.

Killops, S. D., Raine, J. 1., Woolhouse, A. D. and Weston, R. J. (1995) Chemostratigraphic evidence of higher-plant evolution in the Taranaki Basin. New Zealand. Organic Geochemistry 23, 429-445.

Killops, S. D. Allis, R. G. and Funnell, R. H. (1996) Carbon dioxide generation from coals in Taranaki Basin, New Zealand: implications for petroleum migration in southeast Asian Tertiary basins. $A A P G$ Bulletin 80, 545-569.

Killops, S. D., Cook, R. A., Sykes, R, and Boudou, J. P. (1997) Petroleum potential and oil-source correlation in the Great South and Canterbury basins. New Zealand Journal of Geology and Geophysics 40, 405-423.

Landais, P. and Monthioux, M. (1988) Closed system pyrolysis; an efficient technique for simulating natural coal maturation. Fuel Processing and Technology 20, 123 132.

Law, B. E. and Rice, D. D. (ed.) (1993) Hydrocurbons from Coal, AAPG Studies in Geology 38.

Littke, R. and Leythaeuser, D. (1993) Migration of oil and gas in coals. In Hydrocarbons from Coal, ed. B. E. 
Law and D. D. Rice, AAPG Studies in Geology 38, pp. 219-236.

Mackenzie, A. S. and Quigley, T. M. (1988) Principles of geochemical prospect appraisal. AAPG Bulletin 72, 399 415 .

McKinney, D. E.. Bortiatynski, J. M., Carson, D. M., Clifford, D. J., de Leeuw, J. W. and Hatcher, P. G. (1996) Tetramethylammonium hydroxide (TMAH) thermochemolysis of the aliphatic biopolymer cutan: insights into the chemical structure. Organic Geochemistry 24, 641-650.

Marzi, R., Torkelson, B. E. and Olson, R. K. (1993) A revised carbon preference index. Organic Geochemistry 20, 1303-1306

Michaelis, W., Richnow, H. H., Jenisch, A., Shulze, T. and Mycke, B. (1990) Structural inferences from organic geochemical coal studies. In Facets of Modern Biogeochemistry, ed. V. Ittekot et al., pp. 388-401. Springer-Verlag, Berlin.

Michelsen, J. K. and Khorasani, G. K. (1995) The kinetics of thermal degradation of individual oil-generating macerals: calibration with microscopical fluorescence spectrometry and bulk flow pyrolysis. Organic Geochemistry 22, 179-189.

Moldowan, J. M., Fago, F. J., Carlson, R. M. K., Young. D. C., Van Duyne, G., Clardy, J., Schoell, M., Pillinger, C. T. and Watt, D. S. (1991) Rearranged hopanes in sediments and petroleum. Geochimica et Cosmochimica Acta 55, 3333-3353.

Monthioux, M., Landais. P. and Durand, B. (1986) Comparison between extracts from natural and artificial maturation series of Mahakam delta coals. Organic Geochemistry 10, 299-311.

Maroto-Valer. M. M., Love, G. D., Murray, I. P., Snape C. E. and Bailey, N. J. L. (1998) Close correspondence between carbon skeletal parameters of kerogens and their hydropyrolysis oils. Organic Geochemistry. this volume.

Newman, J, and Newman, N. A. (1982) Reflectance anomalies in Pike River coals: evidence of variability in vitrinite type, with implications for maturation studies and "Suggate Rank". New Zealand Journal of Geology and Geophysics 25, 233-243.

Newman, J., Price, L. C. and Johnston, J. H. (1997) Hydrocarbon source potential and maturation in Eocene New Zealand vitrinite-rich coals: insights from traditional coal analyses, and Rock-Eval and biomarker studies. Journal of Petroleum Geology 20, 137-163.

Newman, R. H., Sim, M. N., Johnston, J. H. and Collen, J. D. (1988) Comparison of aromaticity and phenolic content as parameters for characterization of coal by ${ }^{13}$ C NMR spectroscopy. Fuel $67,420-425$.

Noble, R. A., Wu, C, H. and Atkinson, C. D. (1991) Petroleum generation and migration from Talang Akar coals and shales offshore NW Java. Indonesia. Organic Geochemistry 17, 363-374.

Orr. W. L. (1983) Comments on pyrolytic hydrocarbon yields in source-rock evaluation. In Advances in Organic Geochemistry 1981, ed. M. Bjorey et al., pp. 775-787. Wiley, New York.

Pepper. A. S. and Corvi. P. J. (1995a) Simple kinetic models of petroleum formation. Part I: oil and gas generation from kerogen. Marine and Petroleum Geology 12, 291-319.

Pepper, A. S. and Corvi, P. J. (1995b) Simple kinetic models of petroleum formation. Part III: modelling an open system. Marine and Petroleum Geology 12, 417452.

Peters, K. E. (1986) Guidelines for evaluating petroleum source rock using programmed pyrolysis. $A A P G$ Bulletin 70, 318-329.
Peters, K. E. and Moldowan, J. M. (1993) The Biomarker Guide: Interpreting Molecular Fossils in Petroleum and Ancient Sediments. Prentice Hall, Englewood Cliffs.

Peters, K. E., Moldowan, J. M. and Sundararaman. P. (1990) Effects of hydrous pyrolysis on biomarker thermal maturity parameters: Monterey Phosphatic and Siliceous members. Organic Geochemistry 15, 249-265.

Powell, T. G. (1988) Developments in concepts of hydrocarbon generation from terrestrial organic matter. In Petroleum Resources of China and Related Subjects, ed. H. C. Wagner, L. C. Wagner, F. F. H. Wang and F. L. Wong. Circum-Pacific Council for Energy and Mineral Resources Earth Science Serial 10, pp. 807-824.

Powell. T. G., Boreham, C. J., Smyth. M.. Russell, N. and Cook. A. C. (1991) Petroleum source rock assessment in non-marine sequences: pyrolysis and petrographic analysis of Australian coals and carbonaceous shales. Organic Geochemistry 17, 375-394.

Quirk, M. M.. Wardroper, A. M. K., Wheatley, R. E. and Maxwell, J. R. (1984) Extended hopanoids in peat environments. Chemical Geology 42, 25-43.

Radke, M., Schaefer, R. G., Leythaeuser, D. and Teichmūller. M. (1980) Composition of soluble organic matter in coals: relation to rank and liptinite fluorescence. Geochimica et Cosmochimica Acta 44, 17871800

Radke, M.. Willsch, H. and Teichmüller, M. (1990) Generation and distribution of aromatic hydrocarbons in coals of low rank. Organic Geochemistry 15, 539-563.

Requejo, A. G. (1994) Maturation of petroleum source rocks - II. Quantitative changes in extractable hydrocarbon content and composition associated with hydrocarbon generation. Organic Geochemistry 21, 91-105.

Ries-Kautt, M. and Albert, P. (1989) Hopane-derived triterpenoids in soils. Chemical Geology 76, 143-151.

Ritter, U., Myhr, M. B., Vinge, T. and Aareskjold, K. (1995) Experimental heating and kinetic models of source rocks: comparison of different methods. Organic Geochemistry' 23, 1-9.

Sandvik, E. L., Young. W. A. and Curry, D. J. (1992) Expulsion from hydrocarbon sources: the role of organic absorption. Organic Geochemistry 19, 77-87.

Saiz-Jimenez, C. and de Leeuw, J. W. (1986) Lignin pyrolysis products: their structure and their significance as biomarkers. Organic Geochemistry 10, 869-876.

Saxby, J. D. (1977) Oil-generating potential of organic matter in sediments under natural conditions. Journal of Geochemical Exploration 7, 373-382.

Saxby, J. D. (1980) Atomic H/C ratios and the generation of oil from coals and kerogens. Fuel 59, 305-307.

Saxby, J. D. and Shibaoka, M. (1986) Coal and coal macerals as source rocks for oil and gas. Applied Geochemistry 1, 25-36.

Schenck. H. J. and Horsfield. B. (1993) Kinetics of petroleum generation by programmed-temperature closedvs open-system pyrolysis. Geochimica et Cosmochimica Acta 57, 623-630.

Schenck, H. J. and Horsfield, B. (1995) Kinetics of petroleum generation: applications and limitations. In Zentralblatt für Geologie und Paläontologie, Teil I, Ch. 11/12. pp. 1113-1117.

Scott, A. C. and Fleet, A. J. (1994) Coal and coal-bearing strata as oil-prone source rocks? Geological Society Special Publication 77.

Smith, J, W., Rigby, D., Luo, B., Song, Z. and Wang. Y. (1994) The determination of the petroleum potentials of terrestrial source rocks. Organic Geochemistry 21, 287-301.

Snowdon, L. R. (1995) Rock-Eval $T_{\max }$ suppression: documentation and amelioration. AAPG Bulletin 79 , 1337-1348. 
Stalker, L., Farrimond, P. and Larter, S. R. (1994) Water as an oxygen source for the production of oxygenated compounds (including $\mathrm{CO}_{2}$ precursors) during kerogen maturation. Organic Geochemistry 22, 477-486.

Sternberg. J. C., Gallaway, W. S. and Jones, D. T. L. (1962) The mechanism of response of flame ionization detectors. In Gas Chromatography. 3rd International Simperium, ed. N. Brenner. J. E. Callen, M. D. Weiss and J. Sternberg. pp. 231-267. Analysis Instrumentation Division. Instrumental Society of America.

Stout. S. A. (1994) Chemical heterogeneity among adjacent coal microlithotypes - implications for oil generation and primary migration from humic coal. In Coal and Coal-bearing Strata as Oil-prone Source Rocks? ed. A. C. Scott and A. J. Fleet, Geological Society Special Publication 77, pp. 93-106.

Stout. S. A.. Boon. J. J. and Spackman. W. (1988) Molecular aspects of the peatification and early coalification of angiosperm and gymnosperm woods. Geochimica et Cosmochimica Acta 52, $405-414$.

Suggate. R. P. (1959) New Zealànd Coals: their Geological Setting and its Influence on their Properties. Nent Zealand Department Scientific and Industrial Rescarch Bullerin 134.

Suggate, R. P. and Lowery, J. H. (1982) The influence of moisture content on vitrinite reflectance and the assessment of maturation of coal. NZ Journal of Geology and Geophisics 25, 227-231.
Suggate, R. P. and Boudou, J. P. (1993) Coal rank and type variation in Rock-Eval assessment of New Zealand coals. Journal of Petroleum Geology 16, 73-88.

Suggate, R. P. and Boudou, J. P. (1996) Revision of the Mahakam coal series: Rock-Eval and Rank(S) relations. Journal of Petroleum Geology 19, 407-423.

Sweeney, J. J. and Burnham, A. K. (1990) Evaluation of a simple model of vitrinite reflectance based on chemical kinetics. AAPG Bulletin 74, 1559-1570.

Sykes, R., Suggate, R. P. and King. P. R. (1992) Timing and depth of maturation in southern Taranaki Basin from vitrinite reflectance and Rank(S). In Proceedings of the 1991 New Zealand Oil Exploration Conference. pp. 373-389. Ministry of Commerce, Wellington.

Tegelaar, E. W, and Noble, R. A. (1994) Kinetics of hydrocarbon generation as a function of the molecular structure of kerogen as revealed by pyrolysis-gas chromatography. Organic Geochemistry 22, 543-574.

Tegelaar, E. W.. de Leeuw, J. W.. Derenne, S. and Largeau, C. (1989) A reappraisal of kerogen formation. Geochimica et Cosmochimica Acta 53, 3103-3106.

Teichmūller. M. and Durand, B. (1983) Fluorescence microscopical rank studies on liptinites and vitrinites in peat and coals, and comparison with results of the Rock-Eval pyrolysis. International Journal of Coal Geology 2, 197-223.

Van Krevelen. D. W. (1961) Coal. Elsevier Science B.V.. Amsterdam. 